\title{
OBSERVATIONS ON SOME TASMANIAN FISHES: PART XXX
}

by E.O.G. Scott

Queen Victoria Museum and Art Gallery, Launceston

(with five tables, three text-figures and three plates)

\section{ABSTRACT}

SCOTT, E.O.G., 1984 (31 viii): Observations on some Tasmanian fishes: Part XXX. Pāp. Proc. R. Soc. Tasm., 118: 187-222, plates 1-3.

https://doi.org/10.26749/rstpp.118.187 ISSN 0080-4703. Queen Victoria Museum and Art Gallery, Launceston, Tasmania.

ANGUILLIDAE. Anguizla australis Richardson, 1841: a xanthic example is reported.

TRACHIPTERIDAE. (a) Trachipterus arawatae Clarke, 1881: two large dealfish catalogued as T. jacksonensis (Ramsay, 1881) are described and figured and their taxonomic status is considered, with special reference to differential growth in T. arawatae and in the present material, it being concluded Ramsay's species is a senior synonym of Clarke's; (b) Zu cristatus (Bonelli, 1820): a Tasmanian specimen previously referred provisionally to this species is here definitively ascribed to it and is made the subject of some additional observations. BOVICHTHYIDAE. Bovichthus variegatus Richardson, 1846: several good series from Greens Beach, northern Tasmania, allow the study of growth and form in a geographically homogeneous population. ATTENNARIIDAE. Kuiterichthys furcipizis (Cuvier, 1817): observations are made on this species, recently added to the Tasmanian list.

\section{INTRODUCTION}

This paper follows the general plan of others in the series. Linear dimensions are given throughout in miliimetres or as thousandths of standard length. The symbols Ls, Lt, TLs and TLt denote standard length, total length, thousandths of standard length and thousandths of total length, respectively. Registration numbers are those of the Queen Victoria Museum and Art Gallery. Certain other conventions are noted in earlier contributions.

\section{FAMI LY ANGUILLIDAE}

Genus Anguizla Shaw, 1803

Anguizza Shaw, 1803, p.15. Type-species, Muraena anguizza Linne.

\author{
Anguizla australis Richardson, 1841
}

Anguizla australis Richardson, 1841, p.22. Type locality: Port Arthur, Tasmania (Lemprière) .

Anguilza australis occidentalis Schmidt, 1928a, p.388, and 1928b, pp.181,198,203, figs 2-9.

\section{Material}

A xanthic example, Lt $582 \mathrm{~mm}$, caught by Mark Purton in the Elizabeth River, $1 \mathrm{~km}$ north of Campbel1 Town.

Xanthic fish

Xanthochroism in fishes is rare. Whitley (1964, p.22) noted the presence in the Australian Museum, Sydney of xanthic specimens of Kyphosus sydneyanus (Günther, 1886), cited under genus SegutiZum Whitley, 1931, and GireZla tricuspidata (Quoy \& Gaimard, 1824): an example of the latter species caught at Stanley, northwestern Tasmania, in which the whole fish apart from the eye was bright canary yellow has been noted (Scott, E. 1980, 
p.112). Of five references to the literature cited by Whitley - Kershaw (1904), Scott (1942), Whitley (1952), Anon. (1956), Haysom (1960) - the first, second and fourth relate to eels. A xanthic eagle ray, MyZiobatis australis Macleay, 1881, has been reported from New South Wales (Whitley 1940, p.226). A second Tasmanian anguillid, from the South Esk at Longford, multicolored in yellow, brown, grey and white, was reported and figured by Scott (1953, p.147, fig.1).

Coloration of present specimen

General color virtually uniform bright canary yellow; an obscure interrupted band some $5 \mathrm{~mm}$ wide of very faint duskiness along lateral line from above preoperculum to about a head length behind vent and some duskiness for about a head length in hinder part of tail; eye blue; vent blackish; pectoral and dorsal wholly bright yellow; anal bright yellow with some proximal-brewnish-patches each some $30 \mathrm{~mm}$ in length, last extending to tip of small caudal fin.

The specimen has a total length of $582 \mathrm{~mm}$.

\section{FAMILY TRACHIPTERIDAE}

Al1 three recent genera of Trachipteridae, Trachipterus Goüan, 1770, Zu Wa1ters \& Fitch, 1960, Desmodema Walters \& Fitch, 1960, are known to occur in Australia; the second being first recorded in our waters by Scott (1983) (though earlier encountered in New Zealand having there been ascribed by Hamilton (1916), Phillipps (1944), McCann (1953) and Whitley (1968) to Trachipterus under three specific names); the third, though known from "al1 tropic and temperate world seas" (Fitch 1964) apparently reported from our waters only as the type specimen of the type-species Trachipterus jacksoniensis [=jacksonensis] polystictus Ogilby, 1897, from near Newcastle, New South Wales. A key to these genera is provided in Scott (1983, p.171).

Two large dealfish in the collection of the Queen Victoria Museum catalogued as Trachipterus jacksonensis (Ramsay, 1881) serve to validate the earlier suggestions (Scott 1983) of the synonymy of that species with T. arawatae Clarke, 1881; secondly, consideration of literature not previously available confirms the earlier provisional determination of the local example of Zu as Z. ef. cristatus (Bone11i, 1800).

Genus Trachipterus Goüan, 1770

For synonymy see Scott (1983, p.172).

Trachipterus arawatae Clarke, 1881

(plates 1,2; text-figure 1)

Trachipterus arowatae Clarke, 1881, p.195, unnumbered figure. Type locality: Arawata, Jacksons Bay, New Zealand.

?Cepola trachyptera Gmelin, 1788, p.1187. Type locality: Adriatic.

Regalaecus [sic] jacksonensis Ramsay, 1881, p.195, pl.20. Type 1ocality: Man1y Beach, Port Jackson, New South Wales.

Regalecus jacksonensis Macleay, 1881, p. 55.

Trachyptems jacksoniensis: Ogilby, 1886, p.43: Marshall 1926, p.123 (specimen)

Trachiptems jacksoniensis: Phillipps, 1927, p.27: Munro, 1957, p.64, fig. 450 ("probably adult of" T. arowatae): Grant, 1978, p.134.

Trachypterus jacksonensis: Stead, 1906, p.217, and 1913, p.492 (photographs of specimen exhibited).

Trachipterus jacksonensis: Hamilton, 1916, p.372, fig. 1 (Waikanae specimen only): McCul1och, 1921, p.25, p1.11, fig.126a, and 1927, (in: Whit1ey, 1927, p.296, p1.25, fig.2), and 1929, p.138: McCulloch \& Whitley, 1925, p.170: Marsha11, 1964, p.135, p1.29, fig.135, and 1966, p.435, p1.29, fig.135.

Trachipterus arawatae: Scott, 1983, p.172, pls 1-3, figs 1-6 (table of Australasian synonymy). 
Taxonomy of Australian trachipterids

Scott (1983) attempted to clarify the confusion in which the systematics of the Australasian trachipterids has been involved. Three names have been proposed for material with an Australian or New Zealand type locality: (a) Trachipterus arowatae Clarke, 1881, (b) T. jacksonensis (Ramsay, 1881), (c) T. jacksonensis ["jacksoniensis"] polystictus Ogilby, 1898. The first of these has frequently been incorrectly relegated in recent years to the genus Desmodema Walters \& Fitch, 1960 (of which (c) is the type-species), while earlier texts listed the common local dealfish under one or other of a number of extralimital species, e.g. Trachipterus trachyptera (Gmelin, 1788), T. arcticus (Brünich, 1788), T. taenia (Schneider, 1801), T. altivelis Kner, 1819 (the name under which Johnston (1883a) listed the first Tasmanian record of a trachipterid), T. spinolae Valenciennes, 1835, T. falx Valenciennes, 1835, T. iris Walbaum, 1838, T. ishikawae Jordan \& Snyder, 1901. The history and status of Ramsay's species (b) are discussed below. Though represented locally only by the type-specimen, Ogilby's taxon (c) has held its place (with some variation in spelling) in Australian texts, in general enjoying its original status, though McCulloch (1921) suggested Ogilby's specimen-was-a-young-example of Ramsay's fish, (b), formally adopting the synonymy in the Check-list (1929): since the establishment of Desmodema it has correctly been referred to that genus. Attention may be called to the fact that in nominating it as the type-species of their genus Walters \& Fitch (1960) cited its date as 1897 , as also did Fitch (1964): the date of publication was 8 February 1898.

Material

Series A: two specimens in the collection of the Queen Victoria Museum and Art Gallery, Launceston, both registered as Trachipterus jacksonensis, (a) Circular Head, northwestern Tasmania, collected 4 November 1942 (H.J. Burgess), Q.V.M. Reg. No. 1943/3, length without caudal $1060 \mathrm{~mm}$, total length $1190 \mathrm{~mm}$, (b) mouth of Ingl is River, northwestern Tasmania, collected November 1943 (R. Inglis), Q.V.M. Reg. No. 1943/122, length without caudal, mouth protracted $1260 \mathrm{~mm}$, mouth not protracted ca. $1230 \mathrm{~mm}$, length of caudal $112 \mathrm{~mm}$; the larger individual is partly severed at two points but remains intact; the bones of the head are damaged.

Series B: eight Tasmanian examples (of which seven only are used in statistics) of Trachipterus arcwatae in the Museum's collection, specified in Scott $(1983, \mathrm{p} .172)$, lengths to caudal base, mm, 100, 212, ca 296, 444, 508, 555, 560, Q.V.M. Reg. Nos 1971/5/3, $1973 / 5 / 3,1957 / 5 / 4,1945.13,1942.1,1973 / 5 / 4,1969 / 5 / 4$. The eighth individual (damaged) has length to caudal base ca $630 \mathrm{~mm}$.

\section{Meristic characters}

Specimen (a) is noted first throughout: an entry in parentheses if preceded by $R$ is from Ramsay (1881), S Stead (1913), H Hamilton (1916), Ma Marshall (1926), Mc McCulloch (in: Whitley 1927), Mu Munro (1957; synoptic). First dorsal 5 (R 5-7, H 6, Mc 5, Mu 5-7), no data for (b). Second dorsal to vent 72 ( $R$ 75) behind vent $c a \cdot 80$, in (b) no satisfactory count possible near origin, from level of operculum to vent 58, anterior to this perhaps a dozen, giving estimated total before vent ca 70 , behind vent 80 (total $\mathrm{H} 174$, Ma 176, Mc 130+, imperfect posteriorly). Pectoral, 12 on both sides, 11 on both sides (R 14, H 11, Ma 14, Mc 14). Caudal 5, 6 (specimen (b) with two strong processes directed backward; p1.2, fig.B). Branchiostegals 6 (H 6, Mc 6). Gill arches 4, slit behind 4 th (Mc ditto), 5 short broad rakers on hind wall of last slit. Gill rakers on anterior arch 14, 12 (Mc 12). Lateral line to vent 65, ca 62 (R "about seventy"), behind vent 38, 40 .

Here and elsewhere linear dimensions are given unless otherwise indicated as thousandths of length to caudal base, treated as standard length, Ls. Entries for (b) accept as

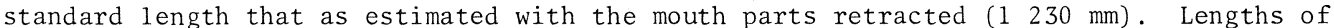
examples noted in the literature: R total length, end of tail wanting, $1422 \mathrm{~mm}$, restored about $1830 \mathrm{~mm}$, S2 $195 \mathrm{~mm}$ plus an estimated $250 \mathrm{~mm}=c a 2445 \mathrm{~mm}, \mathrm{H}$ approximate $1 \mathrm{y} 1830 \mathrm{~mm}$, Ma $1925 \mathrm{~mm}$ (snout protracted), Mc $1929 \mathrm{~mm}$, incomplete, Mu synoptic, $2134 \mathrm{~mm}$. Head 108, ca 114 (R 111, H 111, Mc somewhat <130, Mu 132). Snout 38, ca 39. Eye horizontal diameter 41, 35, vertical diameter 36, 31 (eye: R 32, S 25, H 34). Interorbital 11 ca 10 (Mc "about $2 / 3$ eye"). Length to pectoral 108, 113. Length to ventral 127, 133. Length to vent 462,469 ( $R$ ca 493, Mc round about 500). Depth at front of eye 77, -, at back of 
eye 85, -, at operculum 127, 130 (S at adjacent ventral insertion 106), at vent 123, 138, maximum 142, 154 (Ma 114, Mc 111, Mu 137), width at same points $11,-; 11,-; 16,14 ; 11,5$; maximum 16, 4 (S 23). Length of caudal 123, 91; of ventral 6,$6 ; 8,7$; of pectoral, left 34,21 , right 31,32 (H 29, Ma 45, Mc 60); pectoral base 9.4, 9.3. Length of longest dorsal ray 77,85 ( $\mathrm{R} 32, \mathrm{H}$ "about $1 / 3$ the height of the body", Ma 46, Mc (100th ray) 52) . Length of longest pterygiophore 51, 51. Maxillary plate length 40, 39, width 22, 23 (Mc "more than half as wide as deep", Mu "twice deeper than long"). Length of premaxillary process 66 , ca 59 .

\section{Proportions}

Some proportions conventionally reported are here noted for specimens (a) and (b), followed in round brackets by some values from the literature, and in square brackets by range and mean, with standard error, of the seven well-preserved specimens of sample $B$.

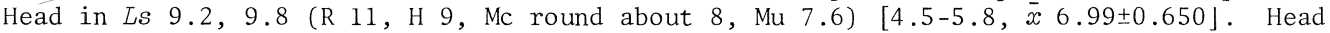
in length to vent 4.3, 4.1 ( $\mathrm{T}$ "four and a-quarter", Mc ca 3.8) [2.8-4.4, 3.74 \pm 0.205$]$. Length to vent in Ls 2.2, 2.1 ( $\mathrm{R} 2.6, \mathrm{H} 2$, Mc ca 2) $[1.4-2.1,1.81 \pm 0.106]$. Greatest depth in Ls 7.6, 6.5 (Ma 8.8, Mc 7.7, Mu 7.6) $13.9-6.3,4.78 \pm 0.524\rfloor$. Depth at vent in Ls $8.6,8.9$ (S 9.4), [5.6-8.5, 7.68 0.444$]$. Depth at vent in length to vent $4.3,4.2$ ( $R$ "four and a-half', H 4) [3.4-4.7, 3.94 \pm 0.148$]$. Mean depth (mean of 10 equidistant measurements) in Ls 12.3, $11.8[6.2-10.7,8.83 \pm 0.725]$. Eye in head 2.6 , ca 3.4 ( $R$ "three and a-half", $\mathrm{H} 3$ ) $[3.2-3.9,3.58 \pm 0.095]$. Snout in head 2.8 , ca $2.9[2.8-3.9,3.25 \pm 0.169]$. Interorbital in eye 3.7 , ca 3.6 (Mc "interorbital width about $2 / 3$ diameter of eye") [1.2-3.1, $1.65 \pm 0.248]$. Length of longest dorsal ray in Ls $12.9,11.7$ (R 31, Mc (50th ray) 19.3) $[5.0-11.6,8.37 \pm 0.845]$.

\section{Description}

Body greatly compressed, width at eye, TLs, 11.3, -; at operculum 16.0, 13.8; at vent $11.3,15.4$, or $7.4,-; 7.9,9.4 ; 10.8,8.9$ in depth there. Pennon shaped, attenuate, more so than as depicted by Ramsay (1881, pl.20) or McCulloch (in: Whitley, 1927, p1.25, fig.2), both their specimens, however, being imperfect posteriorly and lacking the caudal fin; markedly more slender than the type specimen of $T$. arawatae and than Victorian examples figured by M'Coy $(1886, \mathrm{p} 1.122)$, as $T$. taenia. Dorsal profile arched, rising slightly from nape to its highest point at about $35 \%$ of standard length, thence curving down regularly. Ventral profile approaching straight to within about one-third head length of vent, thereafter continuing backward still approximately straight, but proceeding upward at an angle of $7^{\circ}-8^{\circ}$ to previous direction. Entire body covered with small dermal tubercles, subcircular or slightly longitudinally elliptical, somewhat elevated laterally but with most of surface flattish; some variation in size, with modal diameter about $1 \mathrm{~mm}$, interspaces from less than diameter (modally) up to twice diameter, shortly behind head about $90 / \mathrm{cm}$; two rows of slightly enlarged tubercles along each pterygiophore; in (b) a band of 2-3 larger, bordering the pectoral girdle behind; a conspicuous band, 5-7 wide but not in regular rows along whole ventral border, greatest width about 7 TLs, womewhat mounded or pointed, some with distinct median projection, members of this band distinctly knobbly to touch, in contrast to significantly smooth feel of general body surface; along lateral line coalescing to form more or less distinct small plates each with a central spine, similar in all respects to those of sample B. These dermal tubercles are referred to in Ramsay's original account as osseous scutes; attention being called to their differentiation as "oblique bands from the interspaces of the rays" and along the abdominal line.

Lateral line begins at the top of the shoulder girdle level with upper border of pupil; after a brief upward convexity proceeding in (a) almost straight to its end, in (b) bending down somewhat in last one-quarter of tail, the variation in its distance from the dorsal profile, specified below, being much more a function of the curvature of the body outline than of its own curvature: in both individuals it reaches, or virtually reaches, the ventral profile some little distance in advance of caudal origin. Measurements of distance from dorsal profile have been made at 10 equidistant intervals, the mean values for (a) and (b) being well represented by the following $3^{\circ}$ polynomial, in which $N$ is serial number of measurement: $H=27.71+35.863 N-7.7808 N^{2}+0.39229 N^{3} ; R 0.983$; predicted (measured) distances, TLs, $56.2(58.0), 71.4(69.0) 75.9(75.2), 71.8$ (73.5), 61.5 (63.8), $47.5(49.1), 32.0(31.9), 17.5(16.3), 6.2(8.3), 0.6(2.0)$. Plates decreasing in size caudad, length near origin of line about $3 \mathrm{~mm}$, at vent 12, near termination 19 , here as 


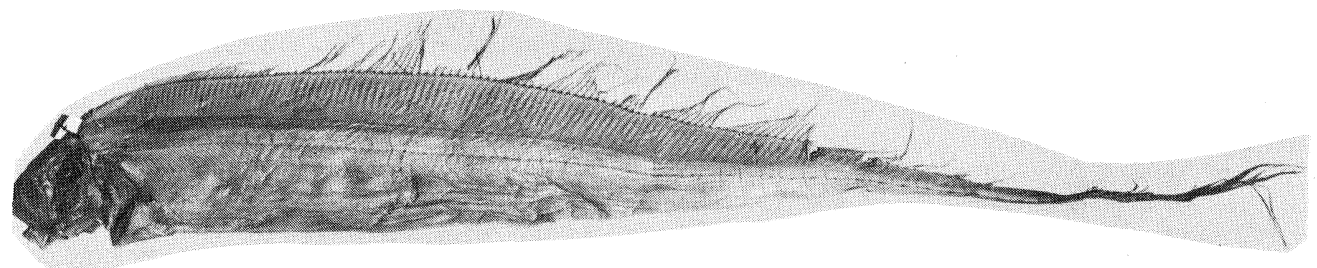

PLATE 1 - Trachipterus arowatae Clarke, 1881 . An example from Circular Head, northwestern Tasmania, length without caudal $1060 \mathrm{~mm}$ (Q.V.M. Reg. No. 1943/3) catalogued as T. jacksonensis (Ramsay, 1881). A: General lateral view $\times$ about 0.1 .

$B$ : Head and anterior part of trunk; $\times$ about 0.33. Photo: R.H. Green.

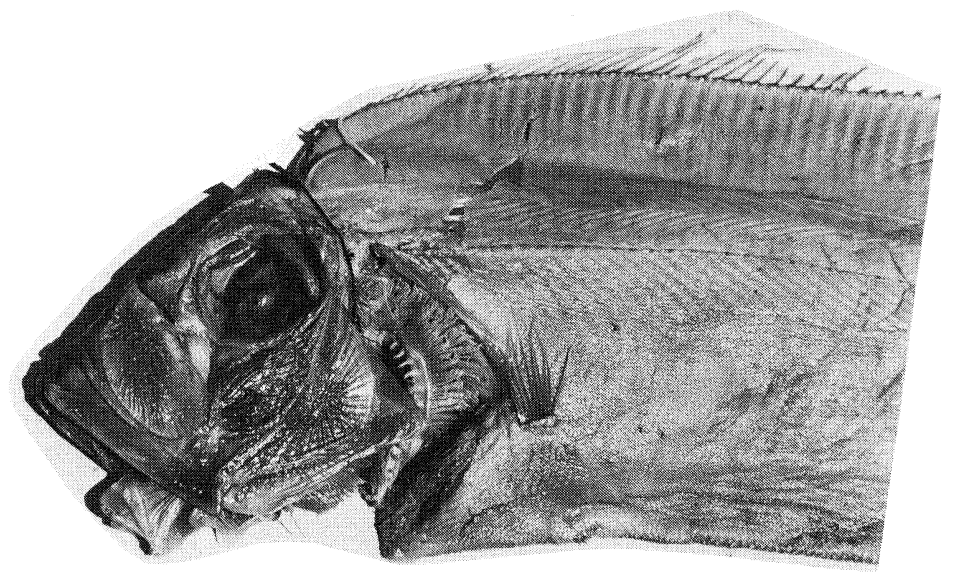

long as the lengthened vertebra; each plate with a single spine, minute anteriorly, progressively increasing in length; on last 8-12 plates about $1.5 \mathrm{~mm}$ long, recurved, in a conspicuous series along ventral border - an average of about one pair of lateral line plates per postanal vertebra is diagnostic of Trachipterus.

A fairly detailed account of the head, accompanied by an illustration, based on sample $B$, has been given in Scott (1983). The specifications given there are in general applicable to the two large individuals of sample A; however some significant points may be noted. Figures by Ramsay and McCulloch show the superior profile slightly convex, a still lesser degree of convexity being presented by our specimens; general overall slope here noticeably greater in McCulloch's plate (about $50^{\circ}$ as against about $40^{\circ}$ ), somewhat greater still in the Tasmanian fish. Premaxillary process terminating above middle of eye, 
distance from eye here 0.3 length of process. Maxillary plate, the proportions of which are generically diagnostic, to below_0.1 eye; its length $1.9,1.7$ its width (M "more than half as wide as deep") [B, 1.5-2.0, $\bar{x} 1.70 \pm 1.003]$, or $2.7,2.9$ in head (estimated from figure R 2.9, M 2.6) [2.4-3.1, 2.71 \pm 0.0890$]$; shape poorly depicted by R, wel1 by M, who correctly indicates the vertically straight segment of the upper part of the anterior border and the small concavity near the middle of the posterior border (this region having applied to it a whitish fleshy or adipose lobe). Distance of eye from dorsal profile fourfifths that from ventral. Nostril a minute vertically elliptical pore, its height somewhat less than $1 \mathrm{~mm}$; border slightly elevated; distance from eye equal to that from profile directly above it, twice that from profile directly in advance of it.

While presenting an essentially similar pattern for the opercular complex, the illustrations of Ramsay and McCulloch show some variation between them in the shapes of the bones, both representations also departing somewhat from our material. In this the preoperculum is more strongly curved, with (contrast Mc) its greatest width near the middle of its length, the length of the chord of the arc of the anterior border about one-eighth of its own length. Damage to the head makes a precise assessment of the operculum difficult; it appears to be more extensive than figured, extending back in a wide 1 obate membranous flap. The preoperculum, which as noted by McCulloch is movable on the exposed processes of the quadrate and hyomandibular, is the most rigid of the bones, though having a smooth membranous border. The truncate ends of the suboperculum and mandible meet beneath the tip of the preoperculum.

Gil1 rakers on anterior arch 14,12 (Mc 12) [4-5, modally 4+9-10, moda11y 9]; uppermost very small, largest at middle of row $4.5 \mathrm{~mm}$, distance between tips $2-3$ times basal diameter; tapering, acute or obtuse, most with 4-5 spines, some with fewer, but up to 9 , best developed on lower border of distal half. As preserved, teeth on premaxillae in (a) 2 on one side, 1 on other, small, in (b) 5 on left, 3 on right, first, 1 argest $2 \mathrm{~mm}$ long, one and a half size of last, not recurved, pointing down and back. In (a) on mandible two large recurved on each side of symphysis, pointing back and down; on vomer 2 , smaller than in mandible; on each palatine 1, smal1: in (b) recognized only in premaxillae. ( $R$ records 4 on either side of lower jaw and 5 on either side of upper jaw, no others mentioned: Mc notes on premaxilla a single irregular row, cardiform, on mandible 2 short rows on either side of symphysis, on vomer 3 in a row, on each palatine 1 or 2) [see details for sample B in Scott (1983, p.182) and generic diagnosis of Trachipterus by Palmer (1961, p.339) "Recurved pointed teeth in both jaws, 6 to 12 in the upper, 6 to 10 in the lower. Vomer with 1 to 2 median teeth. Palatine teeth, if present, feeble."]

As in sample B and apparently regularly in Trachipterus and $Z u$ vent is on midventral line - contrast Desmodema polysticta in which (Walters \& Fitch 1960, p.446) it is often on the right or left side - small horizontally elliptical opening with some peripheral aggregation of dermal tubercles, in anterior half of fish without caudal, at 452469 TLs behind snout tip (R, tail imperfect, calculated 795) [414-620 (i.e. in front or hind half), $\bar{x} 547.6 \pm 27.92]$.

The first dorsal is recognizable on $1 y$ in (a), the whole area being badly damaged in (b). Vestiges of 5 rays are recognizable (R 5-7, Mc 5) [5-7, ?8], 3 imperfect measuring $4.8,6.6,7.6$ TLs; base 4.8. Second dorsal with in (a) 72 rays to vent, ea 80 behind it, in (b) estimated $70+80$ ( $R 75$ to vent) [in 5 specimens of sample $B$ in which satisfactory counts can be made $171,173,174,178,178]$. Rays smooth, slender, finely pointed, often filamentous distally. Length of longest ray 77,85 , ray above vent 66 , ca 65 . Fin traceable to penultimate vertebra.

In his description of his Regalaecus jacksoniensis Ramsay states, "The membrane between the dorsal rays is not attached to the back, but only at the base of each ray", and small void lunules are evident in the plate. No mention of the imperfect attachment of the membrane was made in the excellent description of the Port Jackson specimen by McCulloch, nor is it shown in his plate; it has apparently escaped the notice of other Australian authors. It was, however, picked up by Hamilton in New Zealand, whose description of an example of T. jacksonensis (1916, p.372, fig.1) from Waikanae, near Wellington (noted as being only the second recorded occurrence of this species in the Australasian 


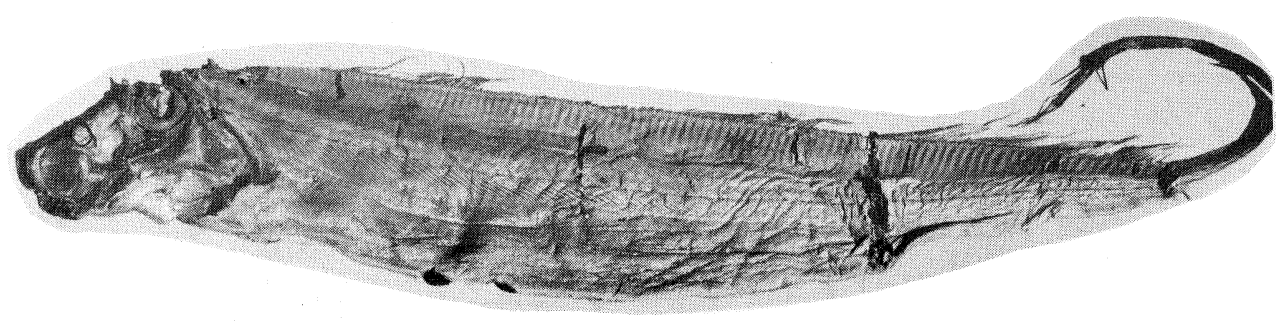

B

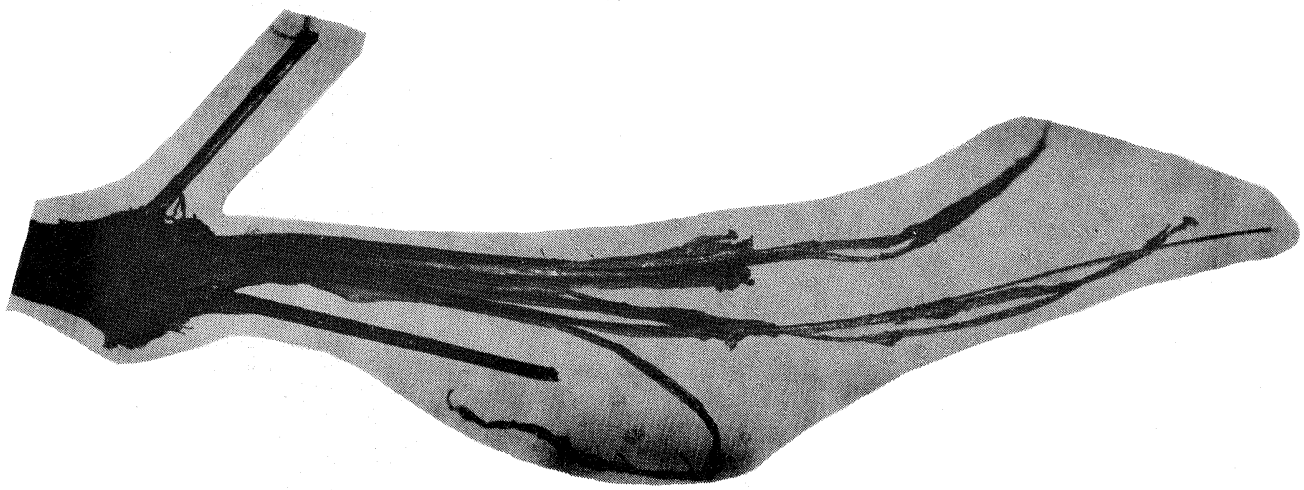

PLATE 2 - Trachipterus arcwatae Clarke, 1881. An example from the mouth of the Inglis River, northwestern Tasmania, length without caudal ca $1230 \mathrm{~mm}$ (Q.V.M. Reg. No. 1943/ 122) catalogued as T. jacksonensis (Ramsay, 1881). A: General 1ateral view, $x$ about 0.1. B: Caudal fin, showing globose base, long flexible rays and two rigid basal processes.. Photos: R.H. Green.

region) was evidently compiled with Ramsay's account before him. He observed it also in four other fish identified as Trachipterus trachypterus (Gmelin) (= T. arawatae Clarke), but made no mention of it in a brief account of a juvenile from Nelson, identified by him as T. jacksonensis, but referable to the genus $Z u$. Further, in his observations on the Waikanae fish Hamilton noted the membrane is double. These conditions obtain also in our material in both samples A and B; the two sheets of membrane, however, being closely apposed and separable only with difficulty.

It is of interest to note this peculiarity of attachment of the dorsal membrane extends beyond the Trachipteridae, occurring also in the Regalecidae, being quite obvious in the example of Regalecus glesne Ascanius, 1778 the subject of some observations (as $R$. pacificus Haast, 1875) by Scott (1982, p.189, p1s 2-4).

Cauda1 5, 6 [6, 8]; length to fin $1060,1230 \mathrm{~mm}$; length of fin 460, 469 TLs [for 5 specimens of $B$ 47-480, $\bar{x} 240.2 \pm 75.6]$. The last normal vertebra compressed, elongate, its length more than twice its width, more than one-third eye (preceded for some distance by similar vertebrae, gradually decreasing in size forward, each with a single median spine) is followed by a wider globose segment, its transverse diameter about half its longitudinal. This specialized segment, presumably housing the hypurals, is not wholly symmetrical; here and in sample B, where it may be more or less fan-shaped, it presents a curious suggestion of having been subject to some distortion. From about the middle onerthird of its posterior border arise the 5, 6 caudal rays, closely set, slender, tending to become filamentous distally, delicately spinose on each lateral surface, their general direction collinear with the vertebral column. In (b) there arise from this segment two rigid slender subcylindrical acute processes, each at an angle of about $45^{\circ}$ to the body axis, the upper, 20 in length, arising from near the junction of the terminal segment with the last vertebra, 
the lower, 30 in length, from the hind border shortly below the lowest ray (p1ate 2, fig. B). One or two much shorter rigid processes in this region have been found in sample B (Scott 1983, p.184). Pectoral 12 (both fins), 11 (both fins) (R, Mc, 14) [11(1), 12(3), 13(3)], inserted immediately behind pectoral girdle, slightly closer to ventral profile immediately below it than to level of lower margin of orbit; base short, about one-fourth eye (R, Mc, figures, approximately half), almost horizontal; rays carried somewhat backwardly obliquely (as in Mc's figure, not almost horizontally as in R's figure), first ray very small, length increasing to fourth, thereafter decreasing, last noticeably shorter than penultimate ( $R$, "the first very small and short", Mc, outer two very short, median longest); bases wider, less closely spaced after $3 \mathrm{rd}$. Lengths of left and right fins in (a) 34,21 , in (b) 31,32 - the marked difference in (a) being perhaps indicative of instability of growth concomitant with the rapid decrease in relative magnitude the fins undergo with increase in overall size of fish. In the left fin of (a) the rays 2-9 (i.e. those other than the small rays at the margins) are significantly specified by the following equation, in which $L$ is length of ray, $N^{1}$ the inverse serial number of ray, counting (Scott 1974, p.248) as the first the uppermost ray: Log $L=0.0305 N^{1}+1.2075 ; t 22.668^{* * *}$; predicted (measured) lengths, TLs, 31.3 (31.1), 28.3 (28.8), 26.4 (25.5), $24.6(24.1)$, $22.9(22.6), 21.4(21.7), 19.9(19.8), 18.6(18.9)$.

In the type specimen of $T$. arcwatae, $64 \mathrm{~mm}$ in length to caudal base, the ventral forms an impressive fan 3.4 times head (Scott 1983, p.183, in error, "in head"), and while it is decidedly smaller in sample $B$, ranging from 0.8 to $1.13, \bar{x} 1.03 \pm 0.098$ in head, or 6.71 .12 in $L s$, it there remains much longer than the pectoral. In the large dealfish identified as T. jacksonensis the ventrals are represented by "a short, slender tubercle on either side of a triangular space opposite the posterior base of the pectoral" (Ramsay), "is worn off, but shows the insertion of two spines in a triangular space opposite the base of the pectoral" (Hamilton), "is either entirely absent or so rudimentary as to be inconsequential" (Marsha11), or appear as "two tubercles in pits in the skin just behind the vertical of the posterior angle of the pectoral base" (McCulloch); "reduced to small tubercle" (Munro). In our sample A they have undergone comparable degradation, being present in the form of a dark brown flap, pennon-shaped in (a), falcate in (b), apparently of a fleshy nature, without obvious indication of rays; length $6.6,8.7$ TLs, or $0.2,0.3$ length of pectoral; inserted behind head by $18.9,18.5$ TLs or $0.17,0.16$ head length; set very closely together, $>2 \mathrm{~mm}$ apart, in the narrow ventral band of the tubercles.

The radialia, pterygiophores, of the second dorsal fin present a conspicuous palisade along the upper half of the fish. Means of lengths of (a) and (b) for 10 measurements taken at equal intervals along general anteroposterior axis of fish range from 2.6 (last decile) to 55.7 (3rd), with overal mean 29.04 56.716 TLs; compare in the generally deeper fish of sample B a maximum height of 45.0-80.0. Their height, being a compound fraction of the dorsal profile and the course of the lateral line (more or less conformable with that of the vertebral column), yields a complex curve when plotted against length of fish, reaching a peak at the $3 \mathrm{rd}$ decile in specimen (a), the 4 th in (b), thereafter being sigmoid. For (a) 10 heights $(H)$, taken at 10 equal intervals (serial number $N$ ) are tolerably satisfactorily specified by a $3^{\circ}$ polynomial: $H=-18.11-50.544 N-10.1272 N^{2}+0.53032 N^{3}$; R 0.889; predicted (measured) heights, TLs, 22.8(22.6), 46.7(45.3), 56.7(59.4), 56.0 $(58.0), 47.7(44.3), 35.6(35.4), 21.4(18.9), 9.3(10.8) 3.1(6.6), 4.9(2.8)$.

\section{Coloration}

Ground color in (a) purplish slate, in (b) becoming slaty below lateral line. Position and form of pterygiophores marked by pale brownish bars, their interspace in (a) greyish in (b) deep cream; at upper end of each a much darker vertical stroke, some 5 TLs long, its upper extremity expanded, its lower pointed. A well-marked band of pale greyish above whole length of lateral line, its width above vent about 20 , somewhat less behind head, decreasing regularly caudad from vent, width halfway to caudal 10 ; from vent backward paralleled by a lesser band below lateral line. Band of tubercles along ventral border lighter than body immediately above it. The myomeres are marked out by conspicuous dark lines, with lighter interspaces once to twice their width, in much of the body, with one full chevron evident above the lateral line and the upper half of a forwardly directed chevron below it, lower part of flank unmarked. Lateral line ranging from orange to brick red, darker round spine base. Head in general dark brown, the plates somewhat shiny, more 
or less uniform. Whole frontal aspect a very dark brown, in parts almost black, bar, extending beyond tips of premaxillary processes to first dorsal origin. Dorsal and pectoral rays bright somewhat olivaceous brown, caudal rays darker; fin membranes translucent.

\section{Ontogenetic change}

Few if any families are characterized by more extensive and striking changes during ontogeny than the Trachipteridae. Four successive stages of development may here be conveniently, if somewhat arbitrarily, recognized: (a) the larval stage, (b) the immediately postlarval stage, (c) the period during which the length of the fish without caudal fin ranges from round about $100 \mathrm{~mm}$ to $500-600 \mathrm{~mm}$, and (d) the period of subsequent growth. The complex history of phases (a) and (b) has been the subject of investigation for upwards of a century, associated with it being the classic researches of Emery $(1879 \mathrm{a}, \mathrm{b})$, followed by contributions from Smitt (1893), Ehrenbaum (1905), Lo Bianco (1908), Jacino (1909), Sanzo (1918), Hubbs (1926), Sparta (1932), Walters \& Fitch (1960), Palmer (1961), Fitch (1964) and numerous other authors. The most obvious developmental features subsequent to stage (c), resulting in marked differences in the general appearance of the fish, include decrease in relative size of the nuchal crest, in that of the pectoral fin and (as reported by Ramsay) in the relative height of the second dorsal, the reduction of the ventrals to vestiges, a modification of the caudal, involving the virtual disappearance of the lower lobe usually accompanied by an alteration in alignment of the upper lobe from oblique to main anteroposterior axis to collinear with it. Attention is directed in the present paper to stages (c) and (d), in particular to an inquiry as to which, if any, quantitative specifications found in, and apparently first reported in, an earlier contribution (1983) to characterize stage (c) as represented by sample B (Ls 100-560 mm) may legitimately be extrapolated to cover the conditions encountered in stage (d) as represented by the present examples of Ls $1060,1230 \mathrm{~mm}$, catalogued as T. jacksonensis (with further reference, where applicable, to the accounts under Ramsay's name by Stead, Marshall and McCulloch).

\section{Differential growth}

It was found earlier that in sample B, with Ls range $100-560 \mathrm{~mm}$, the relative lengths of a number of features are correlated (in all major items, other than length of tail, negatively) with overall size; graphs of growth of head, trunk, tail there being shown (Scott 1983, fig.1). The differences in magnitude are considerable, the mean value for the three specimens of Ls 508-560 mm being for the head only 53\%, for the trunk $93 \%$, for the tail $135 \%$ that of the smallest individual (Ls 100). While trunk length exhibits consistent decrease, the graph resulting when it is plotted against standard length is neither significantly linear with arithmetic values nor significantly linear as a rectified logarithmic formulation. Accordingly the equation for length of head is here complemented with that for tail.

Table 1 sets out equations of regression of logarithmic lengths, TLs, of selected features on standard length, mm, in sample B, recording mean measured and estimated values of the three large individuals of $B$ ( Ls 505, 555, $560 \mathrm{~mm}$ ), together with extrapolations to the overall lengths of the two large specimens of sample $A$ and to those of the still 1 arger dealfish identified as T. jacksonensis by Ramsay (1881), Stead (1913), Marshal1 (1926) and McCulloch (in: Whitley 1927). For all features considered, linear formulations give negative measures of length for all four large specimens in the literature (and in most instances also for specimens of sample A): accordingly only logarithmic equations are given in the table.

With conspecificity of samples A and B assumed, three models suggest themselves for cases in which the relative magnitude of the relevant morphological feature is less in $\mathrm{A}$ than in the small individuals of B. In the first of such models, which may be designated that of arrested change (decrease), the values for $A$ are subequal to those for the larger individuals of $\mathrm{B}$; in the second, the model of steady rate change (decrease), the values for $A$ are subequal to those that would result from extrapolation from a regression equation for $\mathrm{B}$ to the standard lengths of $\mathrm{A}$; in the third, the model of variable rate of change (in the form of an increase), the values for A are noticeably less than those yielded by such extrapolation. 


\section{Trachipterus arowatae Clarke, 1881}

Differential growth. Equation of regression of logarithmic magnitudes, as thousandths of standard length, of ten morphological features on standard length, Ls, mm, in seven individuals, Ls 100-560 mm (sample B), with mean value for three larger specimens; and with extrapolations for two specimens, Ls $1030,1230 \mathrm{~mm}$, catalogued as T. jacksonensis (Ramsay, 1881) (sample A), also for Ramsay's type specimen and for three large fish identified as Ramsay's species by Stead (1913), Marshal1 (1926), McCulloch (in: Whitley, 1927); $M=$ measured, $E$ = estimated.

Feature

$$
\log X=m L s+c
$$

$$
t
$$

SAMPLE B

$$
\text { SAMPLE A }
$$

$$
\text { spec. (a) spec. (b) }
$$

$$
\mathrm{m} \times 10^{4} \quad \mathrm{c}
$$

Length of head

Length of tail

Maximum depth

Depth at vent

Mean depth

Length to pectoral

$$
\text { origin }
$$

Length to ventral

$$
\text { origin }
$$

Length of longest dorsal ray

Length of pectoral

Length of ventral$$
5.723 \quad 2.3791 \quad 8.044 * * *
$$

$4.190 \quad 2.4815 \quad 20.509 * *$

$4.7162 .4615 \quad 4.626 * *$

$3.200 \quad 2.263910 .276 * * *$

$6.707 \quad 2.3366 \quad 12.421 * * *$

$6.044 \quad 2.3799 \quad 8.100 * * *$

$5.6462 .43738 .198 * * *$

$5.890 \quad 2.3295 \quad 11.900 * * *$

$8.1512 .0710 \quad 10.931$ ***

$1.0092 .5774 \quad 4.980$ **

$$
\begin{array}{llllll}
M & \text { E } & \text { M } & \text { E } & \text { M } & \text { E }
\end{array}
$$

$116 \quad 118$

$514 \quad 511$

$\begin{array}{ll}167 & 161\end{array}$

$128 \quad 123$

$95 \quad 94$

$109 \quad 113$

$136 \quad 136$

$103 \quad 103$

$42 \quad 46$

$113 \quad 108$ $\begin{array}{llll}109 & 59 & 114 & 47\end{array}$

$\begin{array}{llll}538 & 843 & 531 & 993\end{array}$

$\begin{array}{llll}150 & 92 & 155 & 76\end{array}$

$\begin{array}{llll}123 & 84 & 138 & 74\end{array}$

$\begin{array}{llll}82 & 48 & 87 & 38\end{array}$

$\begin{array}{llll}108 & 55 & 113 & 43\end{array}$

$127 \quad 69$

$\begin{array}{llll}77 & 51 & 85 & 40\end{array}$

$\begin{array}{llll}34 & 16 & 21 & 12\end{array}$

$\begin{array}{llll}7 & 32 & 9 & 22\end{array}$
Extrapolations from published accounts (estimates from text or Ramsay McCulloch Marshall Stead

$$
\begin{array}{llll}
22 & 19 & 18 & 10
\end{array}
$$

$\begin{array}{lllll}1770 & 1941 & 2048 & 3.106\end{array}$

$40(125) \quad 36(13) \quad 34(114) \quad 20$

$\begin{array}{llll}48 & 44 & 43 & 30\end{array}$

$\begin{array}{llll}18 & 16 & 15 & 8\end{array}$

18

19

25

16

15

22

18

$4(63)$

16

$3(60)$

21

15

$3(45)$

4 
Figures 1A-1J show for all individuals of A and B (for length of pectoral, only six measurements, both fins imperfect in example of Ls $100 \mathrm{~mm}$ ) the value for each of the ten morphological features included in table 1, with the best straight line added. The very small magnitudes resultant upon extrapolation to the standard lengths of the large examples noted in the literature afford a striking demonstration of the proposition that the progressive relative variations (decreases) found in the smaller specimens cease to operate at a standard length of about $600 \mathrm{~mm}$.

It is found the first model, predicating the cessation of differential growth at the upper limit of overall size in B and thus being indicative of the virtual achievement there of the adult conformation is valid for the following features: lengths of head and of tail, depth (maximum, at vent, mean), lengths to origins of pectoral and ventral fins, length of longest dorsal ray, all dimensions being logarithmic values. The situation regarding the lengths of the paired fins is a different one, the graph for length of pectoral (fig. 1I) being best interpreted as a continuation of relative decrease at a decreased rate, while that for length of ventral (fig. $1 \mathrm{~J}$ ) is clearly indicative of an accelerated rate of decrease. While it would clearly be more satisfactory to have data from a more extensive sample than the present, the material here examined appears to provide good evidence that in respect of general body shape and proportions a close approximation to the adult state is reached at a standard length of round about $600 \mathrm{~mm}$, with the paired fins, particularly the ventral, and the nuchal pennant continuing to suffer relative diminution with increase of overall size of fish. In view of the exponential nature of the growth process the acceptable formulations are predictably found to be logarithmic.

\section{Status of Ramsay's species}

As is evident from the table of synonymy provided above, Regalaecus jacksoniensis Ramsay, 1881 - by all authors after Macleay (1881), who emended the generic spelling to the conventional Regalecus, referred to Trachipterus - has with few exceptions been accepted by Australasian writers as a valid species [with in some instances some unfortunate taxonomic confusion, e.g. by Hamilton (1916) who, while correctly ascribing his Waikanae fish (fig. 1) to T. jacksonensis, also applied this name provisionally to a fish from Nelson (fig. 2) in fact a species of $\mathrm{Zu}$, a similar course to this latter being definitively adopted by Phillipps (1944)], a procedure continuing to prevail till quite recently (Grant 1978). However, as early as 1898 in his paper on T. jacksoniensis [= jacksonensis] polystictus, since proposed (Walters \& Fitch 1960) as the type-species of Desmodema, in discussing the general taxonomy of Australian trachipterids, Ogilby stated "I think, however, that the individual described by Ramsay from Manly Beach is the adult form of those so beautifully figured by $M^{\prime}$ Coy from Portland [M'Coy (1886) identified as T. taenia = T. arawatae] nor [sic $=$ and] that Hutton's and Johnston's fishes [Hutton 1873, 1876, Johnston 1883a, identified as T. altivelis = T. arowatae] must be placed in the same category with the latter, the dark spots on most of these examples being merely indicative of immaturity. Ogilby's remarks were considered by Hamilton (1916) who, however, on the basis of the character of fin rays, tended to favour a contrary view. Some six decades after Ogilby's paper his suggestion was again advanced by Munro, who in his Handbook, while giving $T$. jacksonensis formal listing (species 450), basing his account largely on Ramsay's and reproducing his figure, observed "Probably adult of species preceding" (449, T. arawatae). The examination now possible of local dealfishes with standard lengths in excess of a metre supports synonymy of Ramsay's species with Clarke's (Scott 1983).

The main points that have been held to distinguish T. jacksonensis from T. arawatae are: (a) larger size; (b) "having the dorsal ray in the forehead reduced into weak, short hair-like spines" [rays] (Ramsay); (c) "front profile of head convex" [T. arawatae "concave"] (Munro); (d) ventral reduced to "a short, slender tubercle" (Ramsay), "either entirely absent or so reduced as to be inconsequential" (Marshall), tubercle in pit (McCulloch); (e) decrease in height of main dorsal fin; (f) reduction in length of pectora1; $(\mathrm{g})$ absence of "the granulations on the fin rays, and also the spiny tubercles at the base of the spines" (Hamilton); (h) absence of pronounced color markings, in particular of large dark spots, characteristically four, in T. arawatae (found also in northern hemisphere species of Trachipterus - a variation in pattern of five spots being a prime diagnostic character of Trachypterus pentastigma Norman, 1922 from Japan). 
With regard to (a) overall size, Ramsay's species as represented by the holotype and specimens ascribed to it by Stead, Hamilton, Marshall, McCulloch ranges in reported length (some individuals imperfect posteriorly) from 1829 to $2445 \mathrm{~mm}$, averaging in excess of $2 \mathrm{~m}$; Munro's synoptic specification "7 feet" $(2.13 \mathrm{~m})$. The obvious question that presents itself is this: if Ramsay's species represents a taxon other than T. arowatae, what and where to be found is the young stage? The distinction noted in (c) is invalid, the slope of the front of the head depending on whether or no the mouth parts of the specimen are protruded (Scott 1983, p.179). It is to be noted in regard to (e), height of second dorsal, that while in those large specimens for which data are available the fin suffers some diminution in attitude, this is more marked in the holotype and in Hamilton's individual than in others. This feature, (e), and features (b), (d), (f), (h), together with reduction to a vestige of the lower lobe of the caudal and often a change from an oblique to a more or less horizontal posture of the other lobe (fin missing in Ramsay's and McCulloch's specimens) are known to occur, though commonly to a lesser degree, in the course of growth of $T$. arcwatae (see section, Differential growth, above), and indeed in that of various species of Trachipterus recognized in the northern hemisphere. In his treatment of the Waikanae specimen of $T$. jacksonensis Hamilton observed, "Unless the adult forms of this lose the granulations on the fin rays, and also the spiny tubercles at the base of the spines, there can be no identity of T. taenia, T. altivelis, or T. polystictus with a form like $T$. jacksonensis, which has no spinules or granulations on the spine rays. As far as at present known, no radical change takes place on the surface of the fin rays with increasing age." As his other examples of Trachipterus, identified as T. trachypterus (Gmelin), had standard lengths of round about 600, 350, 285, $270 \mathrm{~mm}$ (estimates from scales given with figs 3-6), and as he goes on to remark that though Hutton in his accounts of two specimens of T. altivelis (Hutton 1873, 1876) makes no mention of granulation of the fins he would have noted it if it were missing and hence it may be assumed granulations were present, the argument has the appearance of being a circular one. In our material it is found that in A in proceeding from the smallest example (Ls $100 \mathrm{~mm}$ ) to the largest (Ls $560 \mathrm{~mm}$ ) the dorsal and caudal rays show some indication of decrease of the intensity of the spinulation and of the size of its elements, the dorsal rays of the largest individual modally being smooth in the distal one-fifth or one-fourth: in both individuals of $\mathrm{B}$ (Ls $1060,1230 \mathrm{~mm}$ ) the dorsal rays are smooth, the caudal distinctly spinose.

Two structures in the type specimen of $T$. arawatae - the "little rudimentary dorsal" behind the main dorsal and the "low rudimentary anal fin" immediately anterior to the caudal origin - the presence of which was stressed by Clarke as distinguishing his species from all published accounts, though not occurring in our specimens catalogued as $T$. jacksonensis, are not relevant to the question of the status of Ramsay's species. Clarke's fish was only $64 \mathrm{~mm}$ in standard length, and these supposed diagnostic characters are now known simply to be those of the postlarval stage, being lost with advancing age (hence not "rudimentary" but vestigial). As Hamilton pointed out the smal1 individual, $66 \mathrm{~mm}$, figured by M'Coy (1886) as T. taenia shows what appears to be a vestige of an anal fin, represented only by a trace in the larger individual, Ls $260 \mathrm{~mm}$. Palmer (1961) reported of an example of $T$. areticus $32 \mathrm{~mm}$ in standard length, "Caudad to the last stained dorsal ray and continuous with it is a lobe containing a number of thin filamentous structures, which may be actinotrichia. There is also a similar structure on the ventral surface, which is not present in the adult."

FIG. 1 - Trachiptems arawatae Clarke, 1881: data for seven examples, standard length 100-560 mm (at left) and two examples, catalogued as T. jacksonensis, standard lengths 1060 , ca $1230 \mathrm{~mm}$ (at right). Logarithmic values of ratio of parameters noted below to thousandths of standard length (vertical axis) plotted on standard length, mm (horizontal axis); illustrating continuation or cessation in the large individuals of differential growth with age exhibited by the smaller individuals. Fig. A, length of head. Fig. B, length of tail. Fig. C, maximum depth. Fig. D, depth at vent. Fig. E, mean depth. Fig. F, length to pectoral origin. Fig. G, length to ventral origin. Fig. H, length of longest dorsal ray. Fig. I, length of pectoral. Fig. J, length of ventral. 


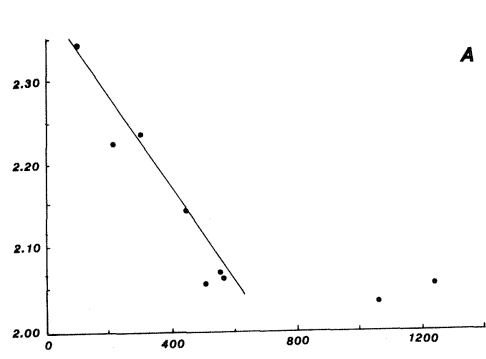

199

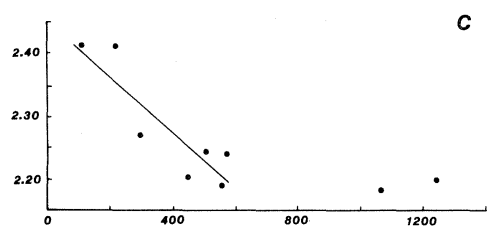

c
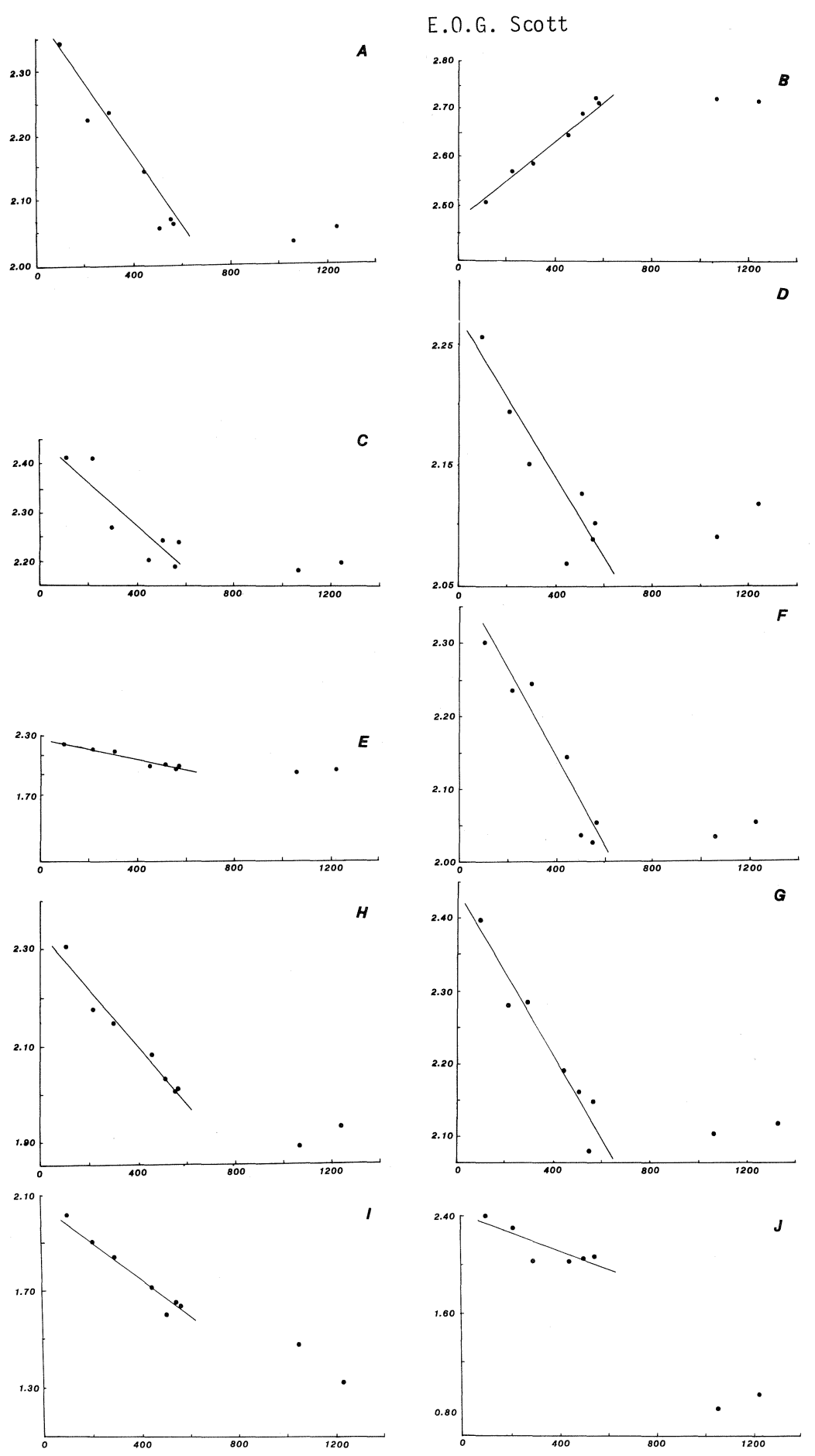

FIG. 1 
It is concluded there appears to be no valid reason for regarding T. jacksonensis as specifically distinct from $T$. arawatae, but there are good grounds for treating it as the adult of the latter. While Ramsay's and Clarke's descriptions were both published in 1881, Clarke's paper (Apri1) has priority over Ramsay's (20 May).

\title{
Genus Zu
}

Zu Walters \& Fitch, 1960, p.445. Type-species, Trachypterus cristatus Bone11i, 1820.

\author{
Zu cristatus
}

Trachypterus semiophorus Bleeker, 1868, p.279, figure. Type 1ocality: Amboina. Trachypterus ijimae Jordan \& Snyder, 1901, p.311, p1.17, fig.9. Type locality: Bay of Tokyo, between Misaki and Bōshu.

Trachipterus jacksonensis: Hamilton, 1916, p.374, fig.2 (Nelson, New Zealand). Nec Regalaecus [sic] jacksonensis Ramsay, 1881.

Trachipterus semiophorus: Fitch, 1964, p.233.

Trachipterus ijima: Fitch, 1964, p.233.

Trachipterus sp., ef. Zu cristatus (Bone11i, 1820): Scott 1983, p.188, pls 1-3 (synonymy). For further synonymic taxa see $\operatorname{Scott}(1983, \mathrm{p} .188)$.

\section{Synonymy}

Two species cal1 for comment. Observing Zu may be monotypic, Palmer (1961, p.347) remarked, "Confirmation of this fact, however, must be left for Walters et al. [i.e. Walters \& Fitch]. It is for this reason that I have not included $T$. ijimae Jordan $\xi$ Snyder 1901 from Japan or T. semiophoms Bleeker 1868 from Amboina in the synonymy of Zu cristatus." These species have since been accepted as conspecific with Bonelli's species by Fitch (1964): examination of illustrations and descriptions of them would suggest the probable validity of the attribution.

\section{Comparison with holotype}

Comparison of our specimen, Ls $405 \mathrm{~mm}$, Lt ca $525 \mathrm{~mm}$, with the description and figure of the holotype, Ls $590 \mathrm{~mm}$, Lt $700 \mathrm{~mm}$, from the Gulf of Spezia reveals good overall agreement of the main diagnostic characters. Some comparative observations (dimensions as thousandths of standard length; holotype cited first): length of head, estimated from figure, ea 178, 136; length to vent 458, 360 [in Scott 1983, p.189 incorrectly given as 146; this is mm not TLs]; length of caudal 186, ca. 296; height of first dorsal 203, 617 [in Phillipps (1964) well in excess of Ls]; height of second dorsal near middle of body 79, 91; maximum depth 212, 156; length of pectoral 68, 56; length of ventral 167, stumps only [in some figured examples in excess of 400]; maxillary plate imperfectly delineated but clearly length greater than (approaching twice) width, 1.85; general outline of trunk subovate, trapezoidal, ventral contour much less boldly scalloped in holotype [in specimen Ls $120 \mathrm{~mm}$, figured by Bachus et al. (1969) head and trunk together subrectangular with scalloping confined to subvertical hind margin; closest in outline to our specimen fig. 2 of Hamilton (1916)]; dorsal 6+114, 6 + ca 130-140 [second dorsal, Phil1ipps 111, Palmer 120-150]; no vesicles on fin rays, paired vestiges; color, fresh, wholly silvery, lacking markings, on collection pink and silvery grey, fins red, after preservation whitish or yellowish with some conspicuous dark brownish markings including three bars behind vent [similar markings depicted by Hamilton (1916, fig. 3), Phillipps (1944, p1.52), Fitch (1964, fig. 1), Bachus et al. (1969, fig. 2)].

Changes during development

Available evidence suggests the ontogeny of $Z \mathcal{U}$ is in general the same as that of Trachipterus s.s. The most noteworthy changes are the decrease in the size of the nuchal crest from a length exceeding that of the entire fish to less than that of head; decrease in relative length of pectoral and ventral, most pronounced in latter; separation of a horizontal caudal fin into a two-lobed structure, the upper fan-like, carried at an angle to the general anteroposterior axis, with subsequent complete or partial reverse of the process; elongation of posterior caudal vertebrae from subequal to the anterior to several times as long. Other changes include the loss of a filament in the ventral caudal lobe; degeneration of a physoclistic swim bladder to a small fibrous vestige; deterioration and 


\section{E.0.G. Scott}

later loss of curious serially arranged structures borne on some fin rays, which at their maximum development take the form of membranous flaps enclosing a bean-1ike body, but later degenerate to small simple flaps, finally wholly disappearing or perhaps being represented by a patch of dark pigment. There appears to be quite considerable individual variation in the degree of development and in the rate of diminution of some of the structures here mentioned.

The only representative of the genus $Z u$ hitherto known from Australia - New Zealand examples have been reported, under the names Trachipterus jacksonensis Ramsay, 1881 (in the present paper regarded as a senior synonym of $T$. arawatae Clarke 1881), T. arcticus Brünich, Desmodema arawatae (Clarke, 1881) by Hamilton (1916), Phillipps (1944), McCann (1953), Whitley (1968) - a specimen from East Inlet, Stanley, Tasmania, described and figured by Scott (1983, p.188, pls 1,2) was there provisionally listed as $Z u$ sp. cf. Zu cristatus (Boenl1i, 1820). Reference to Bonelli's original paper, not then available, and to other relevant literature now leads to the conclusion this specimen is appropriately referred to Bonelli's extralimital species; and it is a purpose of the present communication to make this definitive attribution.

\section{Lateral line}

There is diversity, amounting to actual contradiction, in the accounts given by authors of the course of the lateral line (Scott 1983). Thus Palmer (1961, p.345) pictured the line as ending at a dorsoventrally contricted part of the fish just behind the vent. He wrote, "Lateral line armed, straight as far as the ventral construction where it joins the lower edge of the body." It is relevant to the discussion below to note that he continued, "Posteriorly from this point the ventral edge of the caudal region is armed with an additional paired series of downwardly directed spines, one on each side of the body." In contrast Walters \& Fitch (1960, p.445) wrote "The lateral line is straight on the trunk, wavy on the tail, and extends onto the caudal filament between the rays where it is once more straight." In their key to families and genera of the Trachipteroidei (p.449) Zu was specified as having "lateral line wavy on tail." Trachipterus and Desmodema (also in the two accepted genera of Regalecidae) "lateral line straight on tail." Thus, if Palmer's specification is accepted, his fish is excluded from the family Trachipteridae as recognized by Walters \& Fitch!

Figures by New Zealand authors depict the lateral line either ending shortly behind the vent - Phillipps (1944), McCann (1953, fig. 6), Whitley (1968, fig.1, main figure, not inset, which is a reproduction from Hamilton) - or more or less obviously continuing along the tail - Hamilton (1916). A plate by Bachus et al. (1969) labelled Zu cristatus shows no sudden dip towards the ventral border in the vicinity of the vent, and the row of spines on the trunk marking the course of the lateral line appears to extend in a continuous line on to the slender tail.

In a paper on ribbon fishes of the eastern Pacific Fitch (1964, p.230), after tracing the lateral line to the level of the operculum, observed, it "then progresses posteriorly in a relatively straight line, reaching the ventral contour about one-half head length behind the anus. From that spot to the caudal fin, the lateral line undulates as scales from opposite sides of the body align the ventral contour." A significant difference between the spines of the lateral line on the trunk and the spines on the tail, highly relevant as regards the status of the latter, appears clearly to have been recognized in the original description of Trachipterus cristatus.

While the position as depicted in Bonelli's (1820) illustration is not wholly clear, there would seem to be indicated a discontinuity of the line of spines on the trunk and the line along the ventral border of the tail, the latter continuing well forward beneath the former [as noted in his text (1820, p.489)].

A further examination of the specimen in the Queen Victoria Museum, Ls $405 \mathrm{~mm}$, complements the earlier account (Scott 1983, p.191). As far as can be determined from this specimen: (a) the lateral line as found on the trunk in the form of a narrow groove armed with a row of small spines ceases some $15 \mathrm{~mm}$, or less than half a head length behind the vent, terminating in an obscure irregular depression about 5-6 mm in length, 1ying within 
$2 \mathrm{~mm}$ of the ventral margin; (b) there is no effective junction between the structures on the two sides of the fish; (c) no extension of the groove caudad of the depression is evident; (d) several fine longitudinal grooves are detectable on the lateral surface of the tail, but none has any direct connection with the depression and two are traceable forward as far as the head, none bears spines; (e) the spines on the tail, some of which project below the lateral surface, appear not to be homologous with those occurring in the groove in advance of the vent on several counts, much larger, associated with large bucklers, no direct contact with lateral line of trunk; the foremost extending anterior to the termination of the obvious lateral line. On the evidence afforded by this individual, the probable conclusions are that the lateral line proper ends near the ventral margin shortly behind the vent and that structures behind this are not part of a normal lateral line. There remains, of course, the possibility, albeit unlikely, that two types of fish are indeed being treated by different authors as conspecific.

Attachment of dorsal membrane

In the descriptions of the type specimens of Regalaecus [sic] jacksonensis from Manly Beach Ramsay stated (1881, p.632) "The membrane between the dorsal rays is not attached to the back, but only at the base of each ray." Incidental mention was made in observations above on specimens in the Queen Victoria Museum, Launceston catalogued as Ramsay's species of its occurrence in the Museum's specimen of Zu. The lack of connection between membrane and body in the interval between rays is by no means conspicuous but is seen on close examination regularly to obtain. As far as the writer is aware this curious condition has not hitherto been reported in any descriptions of this species or depicted in illustrations of it.

\section{FAMILY BOVICHTHYIDAE}

Of the four families Nototheniidae, Bathydraconidae, Channichthyidae, Bovichthyidae comprising the suborder Notothenioidei, a group of primarily antarctic and subantarctic fishes, on 1y the last - the name of which, partly as an outcome of the emendation by Agassiz (1845) of the type-genus Bovichtus Valenciennes, 1831 to Bovichthys, has appeared as Bovichthyidae (which has received the imprimatur of Greenwood et al. (1966) in their provisional classification of living teleosts), Bovictidae, Bovichtidae (adopted in the Checklist), Bovichthiidae - has ventured into Australian waters, although nine species of Nototheniidae are reported from New Zealand (Whitley 1968). All three Australian species are recorded from Tasmania, namely Bovichthys variegatus Richardson, 1846, B. angustifrons Regan, 1913 (the distinction of which from Richardson's species is not satisfactorily established), Pseudaphritis bursinus (Cuvier, 1830) (appearing in the Checklist (McCulloch 1929) as $P$. urvilZii (Valenciennes, 1831); there treated as the sole representative of a separate family, Pseudaphritidae).

Observations on one or other of the Bovichthyidae appear in these contributions in Scott (1953, includes key to Tasmanian species; 1957; 1960; 1982).

\section{Genus Bovichtus Valenciennes, 1831}

Bovichtus Valenciennes, 1831, 8, p.486. Type-species CaZzionymus diacanthus Carmichael. Emended to Bovichthys by Agassiz (1845).

\section{Bovichtus variegatus Richardson, 1846}

$$
\text { (Text figs 2, 3) }
$$

Bovicthys [sic] variegatus Richardson, 1846, p.56, p1.39, figs 1-4. Type 1ocality: Port Jackson, New South Wales.

Bovichtus variegatus: McCulloch, 1929, p.336: Parrott, 1948, p.145, p1.31, fig.4: Scott, 1953 , p.155, and 1957 , p.152.

Bovichthis [sic] roseo-pictus Hutton, 1904, p.148. Type locality: Sumner, New Zealand. ?Bovichtus angustifrons Regan, 1913, p.255, p1.4, fig.1. Type locality: Tasmania (one of two types without locality data). 
Material

Six series collected in 1969 (one) and 1976 (five) at or near Greens Beach, northern Tasmania, by Mr R.H. Green, Zoologist, Queen Victoria Museum: (a) Greens Beach, collected 14 December 1969, 44 specimens, Q.V.M. Reg. No. 1972/5/167; (b) north of Greens Beach, 10 March 1976, 7, 1976/5/76; (c) $1.6 \mathrm{~km}$ north of Greens Beach, 24 March 1976, 43, 1976/5/88; (d) $1 \mathrm{~km}$ north of Greens Beach, 7 April 1976, 15, 1976/5/104; (e) $2 \mathrm{~km}$ north of Greens Beach, 16 April 1976, 69, 1976/5/118; (f) $3 \mathrm{~km}$ north of Greens Beach, 21 April $1976,41,1976 / 5 / 133$

Scope

A valuable biometric analysis of 30 specimens from eight localities in New Zealand and neozealanic islands has been provided by Parrott (1948). This was discussed by Scott (1953, p.155), comparison there being made of his data with (a) descriptions of the type specimens 200, $130 \mathrm{~mm}$ from Port Jackson, (b) Waite's (1909) account of a rock-pool specimen $55 \mathrm{~mm}$ long, (c) 11 examples obtained in 1952 by the use of derris in a single rock pool at Penguin, northwestern Tasmania, Ls $38.0-56.8, \bar{x} 46.31 \pm 1.39 \mathrm{~mm}$. The object of the present investigation is to extend and supplement the results noted in the 1953 paper, with special attention being paid to size classes, differential growth and some aspects of form. While material in the Museum's collection additional to that specified above, including series from the west coast and the east coast, has been looked at, only the 219 specimens from Greens Beach or nearby are here reported upon, advantage being taken of the excellent opportunity they afford to assess a population of this species from what is effectively a single locality. The present communication usefully complements the valuable data in Parrott's paper, in that the material here examined is all from a single locality, whereas of his 30 specimens 21 were from various localities in New Zealand itself and the rest from four different neighbouring islands.

\section{Maximum size}

The largest individual among the material listed above has a standard length of $127 \mathrm{~mm}$, or $9.9 \%$ more than the next largest member of sample (f), or $24.2 \%$ above the average standard length of this sample; its total length is $147 \mathrm{~mm}$ : it is possible this specimen may belong to the next age class. The largest example in the Museum's collections, from Smiths Gulch, western Tasmania, has a standard length of 137 and a total length of $162 \mathrm{~mm}$. Overall length is given by Johnston (single specimen) as $133 \mathrm{~mm}$, by Waite (single specimen) as $55 \mathrm{~mm}$, by Lord \& Scott (1924) as $280 \mathrm{~mm}$, by Scott et al. (1974) as $280 \mathrm{~mm}$, by Last et al. (1983) as $300 \mathrm{~mm}$ : the largest example in New Zealand material discussed by Parrott had a standard length of $196 \mathrm{~mm}$.

\section{Abundance}

Johnston (1883a) noted "rare" and (1883b) "extremely rare" but immature examples are often taken in the Derwent Estuary (Lord \& Scott 1924). It is abundant in rock pools along the northern coast and at least in some parts of the west and east coasts. The sample of 11 juveniles from Penguin noted above was collected in a single pool with maximum dimensions of 2.6 by $1.7 \mathrm{~m}$, where this species was associated with Heteroclinus perspecillatus Valenciennes, 1836, Pictiblennius tasmanianus (Richardson, 1849) Creocele cardinalis (Ramsay, 1882), and Alabes rufus (Macleay, 1881). [Last-named species identified - perhaps not altogether satisfactorily - by Springer \& Fraser (1976) with A. dorsalis (Richardson, 1845)]. This fish is more or less cryptic, which may perhaps go some way to accounting for Johnston's unfamiliarity with it. With the advent of scuba diving it has become much more widely encountered. Last et al. (1983) rank it as among the most common fish found in caves and under ledges of shallow coastal reefs, noting small groups "are frequently seen by divers resting vertically or upside down on rock faces or pylons of jetties." The species is quite common and widely distributed in South Australia (Scott et al. 1974) and although the type locality is Port Jackson, New South Wales, McCulloch (1922) remarked that it has not since been recognized in that State and no specimens from the nominal type locality are present in the collections of the Australian Museum, Sydney (Dr J.R. Paxton, pers. comm.).

Standard length in present material

Among the 219 specimens of the six series here dealt with the standard length in millimetres ranges from 28 to 127 , individuals of $<33$ being found only in (a) This series 
TABLE 2

Bovichtus variegatus Richardson, 1846

Specification of standard length, $\mathrm{mm}$, of 6 series, 219 specimens, from

Greens Beach and vicinity, northern Tasmania.

\begin{tabular}{crl} 
Series & $N$ & \multicolumn{1}{c}{ Range } \\
(a) & 44 & $28-50$ \\
(b) & 7 & $43.5-108$ \\
(c) & 43 & $37-119$ \\
(d) & 15 & $38-103$ \\
(e) & 69 & $41-107$ \\
(f) & 41 & $33-127$
\end{tabular}

$\bar{x}$
$.4 \pm 10.06$
$.1 \pm 10.72$
$.1 \pm 4.04$
$.2 \pm 6.06$
$.9 \pm 2.26$
$.5 \pm 3.85$

V

was collected in summer (December), the other five in autumn (March, April), and may be taken as including the youngest examples in the collection: of its 44 specimens, 10 measure 30 or less, and 25 are smaller than the smallest in the next series (10 March). "Juveniles are common in rock pools during autumn" (Last et al. $1983, \mathrm{p} .426)$. The six series are specified for standard length in table 2 .

Age classes

The high coefficients of variation there 44.2 set out - V lowest, (a) 17.9 - are indicative

3.4 of heterogeneity: in the absence of information

43.4 on possible sex dimorphism this is here attrib39.6 uted to difference in age. Examination of a11 36.3 distributions reveals, first, a set of smal1 36.3 individuals, $A$, with an Ls maximum of $60 \mathrm{~mm}$, 38.7 clearly separated by an interval of $13 \mathrm{~mm}$ from the next largest; secondly, a less decisive difference between a group of moderate-sized

and a group of larger individuals. The point of demarcation between these latter two taken, somewhat arbitrarily in its precision but clearly valid in its general slope, is such as to yield in all three recognized size classes, here interpreted as year classes, A $28-60$, B 73-87, C 88-127 mm. Ranges, means (with standard error), coefficients of variation for these are set out in table 3 . The mean values may be empirically, if possibly somewhat adventitiously, specified thus $(N=$ year number $) L=120.1610 g N+44.86$; t 64.328; predicted (measured) lengths, mm, 44.9(45.1), 81.0(80.5), 102.2 (102.5).

TABLE 3

Bovichtus variegatus Richardson, 1846

Standard length, mm, of three suggested age classes in 6 series, 219 specimens, from Greens Beach and vicinity, northern Tasmania.

\begin{tabular}{|c|c|c|c|c|c|c|c|c|c|c|c|c|}
\hline & & $N$ & & & Range & & & $\bar{x}$ & & & $V$ & \\
\hline Series & $\mathrm{A}$ & B & $\mathrm{C}$ & $\begin{array}{c}A \\
(28-60)\end{array}$ & $\begin{array}{c}\mathrm{B} \\
(73-87)\end{array}$ & $\begin{array}{c}\mathrm{C} \\
(90-127)\end{array}$ & A & B & $\mathrm{C}$ & $\mathrm{A}$ & B & $\mathrm{C}$ \\
\hline (a) & 44 & 0 & 0 & $28-50$ & - & - & $37.4 \pm 1.01$ & - & - & 17.9 & - & - \\
\hline (b) & 5 & 0 & 2 & $43.5-50$ & - & $103-108$ & $47.6 \pm 1.13$ & - & $105.5 \pm 2.50$ & 5.3 & - & 3.4 \\
\hline (c) & 29 & 6 & 8 & $37-57$ & $73-87$ & $92-119$ & $46.3 \pm 1.05$ & $79.9 \pm 2.01$ & $105.9 \pm 4.16$ & 12.8 & 6.2 & 11.1 \\
\hline (d) & 10 & 3 & 2 & $38-50$ & $77-85$ & $100-103$ & $43.9 \pm 1.22$ & $82.3 \pm 2.67$ & $101.5 \pm 1.50$ & 8.8 & 2.2 & 2.1 \\
\hline (e) & 46 & 14 & 9 & $41-59$ & $73-87$ & $90-107$ & $49.3 \pm 0.72$ & $79.9 \pm 1.03$ & $96.6 \pm 1.84$ & 9.9 & 4.8 & 5.7 \\
\hline (f) & 31 & 3 & 7 & $38-60$ & $80.5-82.5$ & $94-127$ & $47.1 \pm 0.80$ & $82.7 \pm 1.48$ & $105.7 \pm 4.65$ & 9.3 & 3.1 & 10.1 \\
\hline
\end{tabular}

Rate of growth

In the age classes A, B, C suggested above the absolute Ls increments, mm, are $35.4,42.0$, the percentage increases being $78.5,27.3$. If the largest individual in (f) is treated separately, the increase on the mean of ( $f$ ) (without that specimen) is $25.4 \mathrm{~mm}$ or $2.5 \%$. With presumed age of $1,2,3$ years the age-length coordinates fall on what could well be the upwardly convex segment of the usual sigmoid growth curve.

\section{Note on growth equations}

Opportunity is here taken to make an observation, of some general relevance in a taxonomic context, on discrimination in the selection of an appropriate equation to represent data on growth. It is conventional in growth studies to use an asymptotic equation, chiefly because, as well as giving a reasonable fit to empirical data, it includes on $1 y$ three parameters, two of which (growth constant, asymptotic level) are interpreted as biologically meaningful - this advantageous feature has, however, been called into question 


\section{E.0.G. Scott}

by Haukioja \& Hakala (1979), who stated "the biological validity of comparisons of parameters derived from different populations is highly dubious."

Four asymptotic equations are in general use: von Bertanlanffy (1938) equation, usually presented (e.g. Ricker 1958) in the form

$$
I_{t}=L_{\infty}\left(1-e^{-K\left(t-t_{0}\right)}\right)
$$

where $L=$ length of animal at time $t, L=$ asymptotic length, $K=$ growth constant, $t_{0}=$ theoretical time with zero length [four formal methods of solving the parameters are available; data by Haukioja \& Hakala (table 2) show that for material examined by them of the values obtained for $S_{\%} \bar{x}$ three were $1.09,1.52,2.37$ times that of the smallest]; Gompertz equation (Winsor 1932)

$$
y_{t}=y_{\infty} e^{-B e^{-C t}}
$$

where $y_{t}=1$ ength of animal at time $t, Y_{\infty}=$ asymptotic length, $C=$ growth constant, $B=$ a constant; logistic equation (Verhulst 1838)

$$
y_{t}=\frac{y_{\infty}}{1+b e^{-K t}}
$$

where $K=$ growth constant, $b=$ a constant; Kruger equation (Kruger 1962)

$$
y_{t}=\frac{Y_{\infty}}{N(t+r)^{-1}}
$$

where $N=$ growth constant, $P=$ a constant. For a given set of populations these four equations yield values of $S_{\%} \bar{x}$, and minimum and maximum values that exhibit not insignificant differences (Haukioja \& Hakala, table 3). Of these equations that adopted by the great majority of Australian and New Zealand authors is the von Bertanlanffy.

On fitting polynomials up to the point at which adding a new term did not improve the result (upper limit is reached in 11 of 15 populations examined at a $3^{\circ}$ equation). Haukioja \& Hakala found "The mean $S_{\%}$ between actual and simulated [predicted] values was $1.28 \pm 0.690$, a lower value than in any of the growth equations considered above (Table 2)"; the least value in that table, that arrived at by the iteration method, being $3.15 \pm 0.629$ (other entries $3.42,9.80,7.46$ ). They concluded "Therefore, with the present material, polynomials contained at most one or two parameters more than ordinary equations and were more accurate." In the light of the observations the writer was led three years ago to examine a number of von Bertanlanffy growth equations appearing in Australian periodicals accompanied by the primary measurements. In each instance it was found the fit provided by a polynomial of the form $Y=A+B x+C x^{2}+D x^{3}+\ldots$ (usually of $3^{\circ}$ ) was better than that given by the published von Bertanlanffy equation.

The point to be made is this. While for purposes relating to general fisheries investigations, having in view the estimation and control of populations, for which a knowledge of the growth constant and the asymptotic level is of immediate significance, the use of one or other of the conventional asymptotic equations is appropriate; on the other hand if the primary aim is the provision for taxonomic purposes of the pattern of growth exhibited by a given sample, a more accurate representation of the measurements can be obtained by the use of a polynomial - a fact that has not always received due recognition in local literature.

\section{Differential growth}

Several features exhibit differential growth at different stages of development, conveniently investigated by assessing their relative magnitude, expressed as thousandths of standard length, as a ratio of standard length. The following results are based on measurements of 153 individuals (106A, 23B, 24C); except where otherwise indicated.

(a) Head. Relative, TLs, head length is inversely correlated with standard length, Ls, means for A, B, C being 432.1, 412.5, 405.3, respectively. In a series (a), which consists wholly of first-year individuals, the TLs mean is notably greater than the 432.1 for the general sample, being 475.3. For this ratio values have been calculated for a11 219 specimens; these are 428.1, 412.4, 407.0. For these magnitudes and the first three noted above the negative correlation of 1 og age with $10 \mathrm{~g}$ length is 0.994 , 0.993 ; values not sufficiently high, however, to yield a formally significant $t$ with $d . f . l$. 
(b) Length to vent. With A, B, C means 573.4, 572.3, 572.6 this remains significantly constant in the sample of 153 individuals. However, in (a), in which mean Ls is only 37.4, the low value of 540.6 is found; incorporation of this with the earlier value (weighted means) gives 569.2, the sequence A, B, C thus coming, at least formally, to be one of increasing magnitude.

(c) Length to first dorsal origin. As with length of head, length to first dorsal origin (this point anterior to opercular border) shows relative decrease with increase in overal1 size: A 323.4 , B 314.1 , C $298.3(r-0.971)$.

(d) Length to anal origin. The correlation here is positive; and though C, 625.0, only marginally exceeds B, 624.9, both these are noticeably larger than A (smallest fish), 608.0 .

(e) Maximum depth. With advancing age the fish decreases slightly in depth. For $77 \mathrm{~A}, 17 \mathrm{~B}, 16 \mathrm{C}$, the respective mean TLs values are $215.9,205.4,202.4$.

(f) Lengths to pectoral, ventral origins. With pooled $17 \mathrm{C}+20 \mathrm{~B}$ compared with 75 A, larger values are met with among larger fish for both fins. Values for pectoral 331.4 and 304.8 , for ventra1 256.6 and 236.7 .

(g) Length of pectoral fin. This has been examined in (e) (A 46, B 14, C 9), in which there is apparent a marked negative correlation between length of fin and size of fish, with means for A, B, C 347.5, 319.1, 308.2. With logarithms of both variates the plot is highly significantly linear ( $\left.t 117.683^{* *}\right)$; predicted lengths $347.6,319.0,308.4$.

(h) Length of ventral fin. With the same material as for the pectoral fin, the lengths for A, B, C are 282.7, 259.1, 248.3. A $\log 10 \mathrm{~g}$ plot of fin length on Ls is again significantly linear ( $t$ 19.309*); predicted lengths 283.0, 258.2, 249.0.

(i) Pectoral-ventral ratio. The pectoral is somewhat longer than the ventral. The relative lengths of the fins are close to constant, the measurements for the 69 fish of series (e) yielding A 1.231 , B 1.236, C 1.242 .

(j) Length of caudal. In series (c) total length is correlated inversely with standard length, length of caudal being 220.7 (220.5), 213.0 (213.5), 208.1 (208.0), the entries in parentheses being those yielded by a linear plot of length of fin on length of fish (intercept 230.2, slope -0.209 , $t$ 13.375). For the larger sample A is out of sequence being less than $\mathrm{B}$, which, however, remains greater than $\mathrm{C}$.

(k) Fin-body relationship. Since the fish as a whole is three-dimensional while the fins regarded as locomotory agents may be taken to be two-dimensional, the speculation presents itself: does some simple relation subsist between the volume of the body and the area of fin? As a gross approximation for investigation the volume may be taken to be a function of $\mathrm{Ls}^{3}$ and the area a function of (fin-length) ${ }^{2}$. For the pectoral the ratio $L s^{3} / \mathrm{P}^{2}$ for $\mathrm{A}, \mathrm{B}, \mathrm{C}$ is $0.992,5.008,9.489$ ( $\mathrm{Ls}$ in millimetres, fin length in TLs). This is correlated with Ls at $r 0.980$ ( $t$ 4.943), while the logarithmic values of the ratio give $r 0.993\left(t 16.064^{*}\right)$. For the ventral the ratios are $1.500,7.596,14.619$, correlated with Ls at $r 0.978$ ( $t$ 4.718), while the 1 og values of the ratio give $r 0.997(t) 13.768 *$ )

(1) Growth in New Zealand material. In an examination of 30 specimens from seven localities in and around New Zealand Parrott (1948) observed of the pectoral, ventral and caudal "There appears to be a somewhat inverse correlation between the length of the fins and that of the fish. In younger or smaller examples the fins grow relatively fast in relation to body growth, while in older or larger individuals the reverse is the case. The Pectoral varied from 3.0 to 4.1 in standard length. The Ventrals are relatively shorter varying from 3.8 to 4.8 in standard length. The Caudal varied from 4.0 to $6.0 . "$ While there is a considerable amount of tabulated metrical data (tables 5, 6, 7) in this paper, the combination of small samples and diversity of source (attention is called at several points to differences in conformation of individuals from different localities), together with the presentation of proportions recorded only to a single decimal place is such that no statistically significant measures of correlation emerge.

\section{Growth gradient}

The gradient of growth along the anteroposterior axis of the fish is shown in fig. 2 , where the lengths to the six morphological landmarks examined as found in sample A (smallest fish) are plotted along the lower line and the means of the pooled sample B (medium) and $\mathrm{C}$ (large) along the upper line; all dimensions as thousandths of standard length. The landmarks clearly divide into three pairs: (i) the paired fins, pectoral and ventral, the lengths to which are less in the larger than in the small fish; (ii) first dorsal origin and head (opercular margin) with values greater in the larger fish; (iii) vent and adjacent 
anal origin with, at hinder end of fish, values again less in the larger fish. With the item for $(B+C)$, mean, expressed as a percentage of that for $A$, the values for the members of each pair are virtually the same - ventral origin $92.5 \%$, pectoral origin $92 \%$; first dorsal origin $105.7 \%$, head $105.7 \%$; vent $98.1 \%$, ana1 $97.3 \%$. A striking feature is the intersection of the lines for pectoral and first dorsal, the pectoral, inserted posterior to the first dorsal in the young fish, coming to lie in front of it in the older. The paired fins thus appear to be under the control of a growth mechanism different from that governing the other features considered. An example of variation in fin sequence in another Tasmanian fish has been noted by Scott (1978). In Schedophilus huttoni (Waite, 1910)

the dorsal origin migrates from a position in advance of pectoral origin in young fish to above that fin in older fish: exchanges of serial order are known to occur in other members of the Centrolophidae (Haedrich 1967).

Though the variations with age in the location of these morphological points along the anteroposterior line constitute quite definite divergences, the differences involved are not very large. While the plot of all the pooled items for $B$ and $C$ on the corresponding items for A can plausibly be dissected into an anterior section and a posterior section with steeper slope, nevertheless it presents overall a very good approach to a single straight line $\left(t 7.690^{* *}\right)$, with a slope, 0.933 , not far from unity. The fact that the intercept is smal1, 30.4, suggests examination of the data with the inclusion of a point with zero coordinates. Such a line has a slope of 0.985 and a negligible intercept of 0.7 ; the correlation coefficient is 0.996 , equivalent to a $t$ value of $24.509 * * *$.

Depth-width relationship

In the course of an examination of two large examples of the other Tasmanian bovichtyid, Pseudaphritis bursinus (Cuvier, 1830), Ls 185, $225 \mathrm{~mm}$, there emerged an interesting relation between depth and width. With ten widths, measured at equal intervals along the anteroposterior axis from most advanced point to hypural joint, plotted against ten depths similarly measured, the plot assumes a sublenticular form, with an upwardly convex curve for the early deciles, terminating near, or on extrapolation becoming continuous with, a longer upwardly concave curve for the later deciles (Scott 1982, fig.8a). Each segment represents a logarithmic arc such that $\log W=m D+c(1982$, fig.8b). In the present species with ten pairs of similar measurements the width-on-depth graph again presents a precise pattern, with two curves converging, here intersecting, at decile 3 . There are, however, noticeable differences from the earlier formulation: first, the arc for deciles 1-3, convex in the other species, is here concave; secondly, the segment for deciles 4-10 (3-10), in Pseudaphritis represented by a single arc, here takes the form of a continuous curve resolvable into two segments, one upwardly convex for deciles 3-7, one upwardly concave for deciles 7-10: i.e. in Pseudaphritis A $\{1-3\} \cap B \quad\{3-10\}$, in Bovichtus A $\{1-3\} \cap$ $B\{3-7\} \cap C\{7-10\}$. As before in each set $\log W=m D+c$. Measurements of depth and width, as TLs, together with the rectified equations for each of the three arcs, accompanied by values predicted by these equations, with an indication of significance are set out in table 4. Graphs for two specimens are presented, one (fig. 3A) for an example of Ls $52 \mathrm{~mm}$, the other (fig. 3B) for an example of Ls $110 \mathrm{~mm}$, both with eye-fitted curves. It will be seen these exhibit a striking difference, that for the small individual having the curve for $\{1,2,3\}$ above the sigmoid curve, that for the larger individual having the former below the latter. The difference relates to the size of the fish, the situation 
TABLE 4

Bovichtus variegatus Richardson, 1846

Depth-width relationship, Log $W=\mathrm{m} D+c$, for five specimens of standard length 52-119 mm; ten measurements of depth and width taken at equal intervals between most advanced point and hypural joint. For each individual three sets, specified by the numerical value of the decile measurements thus $\{1-3\} \cap$ $\{3-7\} \cap\{7-10\}$.

\begin{tabular}{|c|c|c|c|c|c|c|}
\hline \multirow[t]{3}{*}{$\begin{array}{l}\text { Ls, } \\
\text { mm }\end{array}$} & $\begin{array}{l}\text { Decile } \\
\text { set }\end{array}$ & $\begin{array}{l}\log W \\
m \times 10^{3}\end{array}=$ & $\begin{array}{c}\mathrm{m} D+\mathrm{c} \\
\mathrm{c}\end{array}$ & Depth, TLs & Estimated (measured) width, TLs & $t$ \\
\hline & $\{1-3\}$ & 3.024 & 1.7792 & $116,183,196$ & $134(135), 215(211), 236(238)$ & $22.808^{*}$ \\
\hline & $\{3-7\}$ & 6.118 & 1.861 & $196,185,173,152,137$ & $243(238), 207(212), 176(173), 130(137), 105(102)$ & $18.158 * * *$ \\
\hline \multirow[t]{3}{*}{52} & $\{7-10\}$ & 2.558 & 1.6609 & $137,87,63,58$ & $102(102), 76(77), 67(67), 64(62)$ & 25.437 ** \\
\hline & $\{1-3\}$ & 3.167 & 1.7159 & $128,190,206$ & $132(132), 207(210), 232(231)$ & $24.025^{*}$ \\
\hline & $\{3-7\}$ & 3.632 & 1.5993 & $206,181,154,136,123$ & $222(231), 180(173), 141(141), 124(122), 111(115)$ & $13.816 * * *$ \\
\hline \multirow[t]{3}{*}{78} & $\{7-10\}$ & 6.806 & 1.2345 & $123,101,77,54$ & $118(115), 84(85), 57(64), 40(38)$ & $17.110 * *$ \\
\hline & $\{1-3\}$ & 1.245 & 1.9744 & $145,182,200$ & $141(145), 185(182), 197(200)$ & 9.453 \\
\hline & $\{3-7\}$ & 0.846 & 2.1007 & $200,202,182,168,155$ & $208(200), 193(202), 180(182), 167(168), 159(155)$ & $5.600 *$ \\
\hline \multirow[t]{3}{*}{110} & $\{7-10\}$ & 4.667 & 1.6362 & $155,127,84,64$ & $154(155), 127(127), 86(84), 63(64)$ & $33.41 *$ \\
\hline & $\{1-3\}$ & 1.326 & 1.9501 & $147,256,283$ & $142(142), 198(198), 215(216)$ & $144.334 * *$ \\
\hline & $\{3-7\}$ & 1.517 & 1.9269 & $283,216,181,140,120$ & $227(216), 179(187), 159(171), 138(138), 129(121)$ & $6.699 * *$ \\
\hline \multirow[t]{3}{*}{116} & $\{7-10\}$ & 2.602 & 1.7506 & $120,93,69,28$ & $116(121), 98(95), 85(82), 67(69)$ & $7.497 *$ \\
\hline & $\{1-3\}$ & 1.634 & 1.8648 & $151,218,227$ & $151(151), 217(218), 228(227)$ & $39.920 *$ \\
\hline & $\{3-7\}$ & 0.667 & 1.1631 & $227,214,216,185,174$ & $232(227), 212(214), 199(206), 187(185), 176(174)$ & $8.361^{*}$ \\
\hline 119 & $\{7-10\}$ & 4.310 & 1.6774 & $174,109,101,66$ & $164(174), 119(109), 101(101), 63(66)$ & $9.107 *$ \\
\hline
\end{tabular}

obtaining in the smaller specimen being duplicated in that for a second small specimen of Ls $78 \mathrm{~mm}$ (the upper curve here approaching closer to the lower than in the specimen of $58 \mathrm{~mm}$ ), the situation found in the larger fish of Ls $110 \mathrm{~mm}$ repeated in other large individuals of Ls $110,119 \mathrm{~mm}$.

\section{FAMI LY ANTENNARIIDAE}

History of family in Tasmania

Important items in the history of this family in Tasmania include the following. (a) No antennariid noted in first two Tasmanian faunal lists (Johnston 1883a, 1891).

(b) Antennarius mitchelzii, type locality Lisdillon, eastern Tasmania, described by Morton (1897, XIV and p.98) [second binomen cited incorrectly in Checklist (McCu11och 1929, p.408) as mitche $2 z_{i}$; this emended form being there adopted and receiving subsequent general currency]. (c) Morton's fish nominated as type-species of genus Trichophryne (McCulloch \& Waite 1918, p.68, p1.6, fig.1) and reported from South Australia and Victoria. (d) Third Tasmanian catalogue (Lord 1923, p.71) lists Trichophryne mitche ZZi [sic] and Histrio

histrio Linné [this species, widely distributed in the Atlantic, east and west Pacific and Indian oceans, is formally recorded from Australia in the Checklist only from New South Wales; no locality record is given by Lord, and it is here suggested its inclusion in the local list is probably an error]. (e),(f) The subsequent catalogues of Lord $\xi$ Scott (1924, pp.14, 89) and of Lord (1927, p.16) repeat the two entries of Lord (1923) without comment. (g) Rhycherus fizamentosus (Castelnau, 1872), with type locality St Vincents Gulf, South Australia, added to Tasmanian list by Scott (1935, p.71, pl.5, fig.2), specimen from Tamar Heads, northern Tasmania. (h) Echinophryne crassispina McCulloch \& Waite, 1918 added to Tasmanian list (Scott 1978, p.312), this species up to now represented locally only by this specimen, from east coast of Flinders Island, Bass Strait. (i) A fourth species, listed as Trichophryne furcipizis (Cuvier, 1817) reported in Last et al. (1983, p.256, fig.22.8) [observations made below on this species and its generic identity discussed]. 

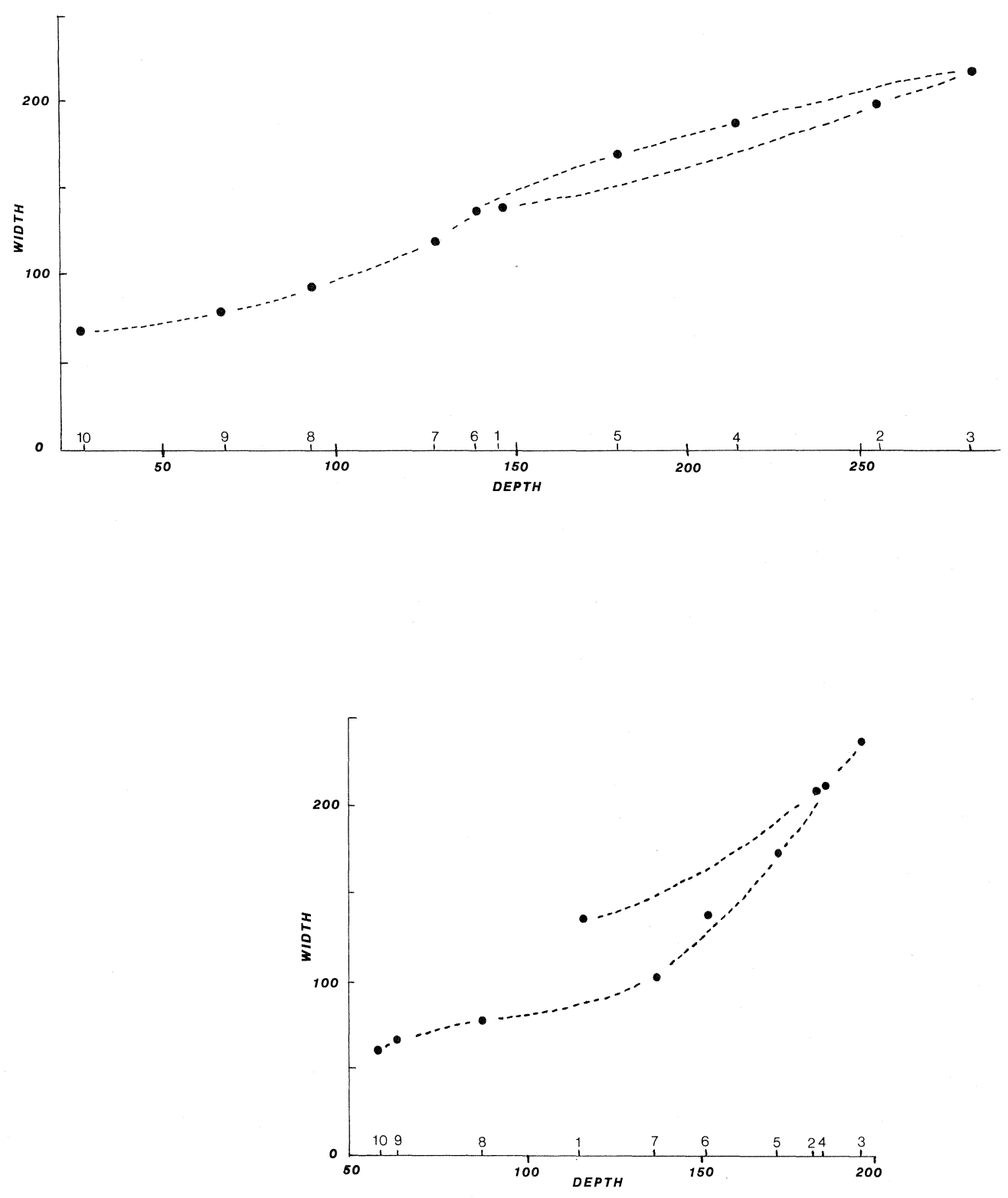

FIG. 3 - Bovichtus variegatus Richardson, 1846. Width (vertical axis) at ten equidistant points (1-10) between tip of snout and hypural joint on depth (horizontal axis) at same points; dimensions as thousandths of standard length. Two specimens from Greens Beach. A (bottom graph), standard length $52 \mathrm{~mm}, \mathrm{~B}, 116 \mathrm{~mm}$. Curves eye-fitted (each figure with three logarithmic arcs). 
Species known to occur in this State may be distinguished by the subjoined key.

\section{KEY TO TASMANIAN ANTENNARIIDS}

1. Skin smooth. Body and second and third dorsal spines with

long cutaneous processes. Second dorsal spine shorter than

first. Lure larger than eye-diameter. Size larger, length

to about $250 \mathrm{~mm}$.
Skin with minute spines or bristles. Body and second and

third dorsal spines without long cutaneous processes.

Second dorsal spine (full length) as long as, or longer

than, first. Lure smaller than eye-diameter. Size smaller,

length to about $150 \mathrm{~mm} \ldots \ldots \ldots 2$

2. Second dorsal spine conical, attached behind in its basal

half or more to dorsum, shorter than longest dorsal ray.

Second dorsal with 15 rays.
Second dorsal spine rodlike, not attached behind in its

basal half to dorsum, longer than longest dorsal ray.

Second dorsal with 13-14 rays.

$\ldots \ldots 3$

3. First dorsal spine covered with delicate skin, bearing

bristles forming a cluster at its tip. Second spine similar to first but with larger bristles. Free portion of third spine shorter than snout.

First dorsal spine naked, glassy. Second spine much

stouter than first, with bristles and usually a few

longer fleshy processes. Free portion of third spine

longer than snout.

........ Kuiperichthys furcipizis

\section{Distribution}

The Tasmanian component of the Australian antennariid fauna presents an interesting chapter in zoogeography. Since the pioneer investigations of Hedley (1904), working on mollusca, it has been recognized the waters around Australia divide into regions, each characterized by a more or less distinct fauna; significant contributions to their specification having been made by, among others, Iredale (1937) (molluscs), Kott (1952) (ascidians), Endean (echinoderms), Whitley $(1932,1937)$ (fishes) - for other references including some by overseas authors, Whitley (1964, p.23) may be consulted. In broad terms the coastline is classified thus: from Shark Bay and Cape Jaubert in Western Australia north and east to Cape York, Damperian; Queensland, Solandrian; south along New South Wales to southern Tasmania, Peronian (with Maugean subregions on Tasmania's east coast, extending northward, for some faunas as far as Port Jackson); from D'Entrecasteaux Channel along the Tasmanian west coast, Victoria, South Australia, south and southwestern coasts of Western Australia, Flindersian. As observed by McCulloch \& Whitley (1958) "The marine fish fauna of Australia is composed of three elements - species derived from the north, southern forms and deep-sea types", an arbitrary line of division being set at $27^{\circ} \mathrm{S}$.

Among the Antennariidae the genera Antennarius Lacépède, 1798 [in the Australian Checklist (McCulloch 1929) genus attributed to Cuvier, 1816], PhryneZox Whit1ey, 1931, Lophiocharon Whitley, 1941 (these two included by early writers in Lacépède's genus) and Tathicarpus Ogilby, 1907 are warm-water genera, confined in Australia to the northern Peronian, the Solandrian and the Dampierian regions, with a number having also a wide extralimital distribution. On the other hand the genera Rhycherus Ogilby, 1907, Echinophryne McCulloch \& Waite, 1918, and Trichophryne McCulloch \& Waite, 1918 are inhabitants of the Flindersian and Peronian regions, to which the first and second are endemic, as also possibly is the third, a Philippine Islands species described by Smith (in: Smith G Radcliffe 1912) as Antennarius rosaceus, but referred by Schultz (1957, 1966) to Trichophryne differing in several noteworthy features from the type-species of that genus (Antennarius mitchellii Morton, 1896, from Tasmania) and being doubtfully congeneric with it.

Thus in general the Australian antennariids divide into northern and southern genera; many representatives of the former being tropical forms with Australia on the southern 


\section{E.0.G. Scott}

fringe of their distribution, whereas the latter lack any components from the south, the New Zealand fauna for instance including a single species, the widespread Phrynelox striatus (Shaw $\xi$ Nodder, 1794), the type locality of which, rendered "Circa 1itora Australasiae" by Banks, is identified by McCulloch (1929, p.407) as Botany Bay, New South Wales [for status of Antennarius pinniceps Commerson, 1837 vis-a-vis this species see McCulloch (1922, p.123) and De Beaufort \& Briggs (1962, p.213)]. The genus Histiophryne Gi11, 1863 as recognized in Australia poses a problem.

The South Australian fish described and figured by McCulloch \& Waite (1918, p.74, p1.7, fig.2) as $H$. scortea (of which a variety, H. s. var. inconstans, is noted) presents - as pointed out in De Beaufort \& Briggs (1962, p.220) - some noticeable differences in the character of the second and third dorsal spines from the fish described and figured by them (p.72, p1.7, fig.1) as H. bougainvilZi Valenciennes, 1837 (type-species of Histiophryne), and indeed from extralimital species that have been referred by other authors to Gill's genus. The provenance of the specimen illustrated in fig.1 is unknown (may not even be South Australia); and the possibilities arise, first, that Gill's genus may not be represented in South Australia, secondly that material described as $H$. scortea may properly be referable to a separate endemic genus of the Flindersian region.

Genus Kuiterichthys Pietsch, 1984

Kuiterichthys Pietsch, 1984, 1, p.37. Type-species Chironectes furcipizis Cuvier. Chironectes Cuvier, 1817, 3, p.418. Type-species Lophius chironectes (Commerson) Lacépède. Batrachopus Goldfuss, 1820, 2 (3), p.110 - substitute name for Chironectes Cuvier, 1817. CapeZZaria Gist1, 1848, p.8 - substitute name for Chironectes Cuvier, 1817.

Kuiterichthys furcipizis (Cuvier, 1817)

(Plate 3)

Chironectes furcipilis Cuvier, 1918, p.329, p1.17, fig.1. "On ignore d'où cette espèce est venue au cabinet." Known distribution: from central New South Wales to just east of the Recherche Archipelago and Tasmania, in depths of 9-24 m (R.H. Kuiter, pers. comm.).

Trichophryne furcipizis: Last et al., 1983, p.256, fig.22.8.

Kuiterichthys furcipizis Pietsch, 1984, p. 37.

Tasmanian history

The account of the species here presented is a revised extract from an unpublished review of the Tasmanian Antennariidae carried out by the writer during the seventies, it therebeing treated as an undescribed species. Shortly before the deadline for submission of this Ms there appeared in Last et al. (1983, p.256, fig.22.8) an account and figure of it under the heading Trichophryne furcipilis (Cuvier, 1817), the entry, Dr Last informs me, having been supplied, on the basis of Tasmanian material made available to him, by Dr T.W. Pietsch. At that time, in the course of a revision of the Australian Antennariidae, he was contemplating referring Cuvier's species to a new genus, Kuiterichthys; now published (Pietsch 1984), the genus being monotypic, locality of holotype knknown. It was indeed evident that with its naked glassy first dorsal spine it could not legitimately be placed in Trichophryne, a diagnostic feature of which is the presence of bristles on that spine (a character that appears in part to have suggested the use of the prefix "tricho-", signifying "hair" or "hairy").

The second binomen furcipizis does not appear, either as a valid or a synonymic taxon, in any of the comprehensive catalogues of Macleay (1881-1884), McCu11och (1929), Munro (1956-1961), Whitley (1964), the fact that the source of the holotype was unknown having led to the failure of the fish to be noted in local literature till quite recently. Cuvier's own vernacular "La Chironecte a poils fourches" suggested the latinized version (1iterally, "fork-skinned"), alluding to the presence on the skin of fork-1ike (bifurcate) spinous processes, developed on tubercles. Chironectes furcipilis is given by Schultz (1957, p.73) as a queried synonym of Phrynelox scaber (Cuvier, 1817), with type 1ocality. Atlantic; but it is clearly distinct from that species. 
Distribution

Last et al, stated "This species is common in D'Entrecasteaux Channe1 [southeastern Tasmania] on muddy bottoms in depths between 15 and 50 metres. It is occasionally found in the catches of scallop dredges." Mr R.H. Kuiter, Seaford, Victoria, in whose honour the species is named informs me (in litt.) "It occurs along our south coast from central New South Wales to just east of the Recherche Archipelago and Tasmania."

\section{Material}

Specimen (a), Ls $113 \mathrm{~mm}$, Lt $140 \mathrm{~mm}$, dredged in D'Entrecasteaux Channe1, October 1921 (Tasmanian Museum and Art Gallery, Hobart; D365; identified as Echinophryne mitchelli); (b) Ls $80 \mathrm{~mm}$, Lt $99 \mathrm{~mm}$, dredged in D'Entrecasteaux Channel near Kettering (Tasmanian Fisheries Development Authority; collected by J. Lion and T.L. Seward, 8/10/1935).

Meristic characters

D. 1, 1, 1, 13. A. 8. P. 10. V. 5. Fig. 22.8 in Last et al. (1983) appears to depict an unexplained total of $6-7$ rays in the ventral.

\section{Dimensions}

Al1 "length to" measurements are taken from the most advanced point on chin: in (a) this is $2.5 \mathrm{~mm}$ (22 TLs) in (b) $1.5 \mathrm{~mm}$ (19 TLs) in front of tip of upper jaw. Length to base of caudal, $L s$, (a) $113 \mathrm{~mm}$, (b) $80 \mathrm{~mm}$, to end of caudal, Lt, (a) $140 \mathrm{~mm}$, (b) $99 \mathrm{~mm}$. All dimensions that follow are recorded as thousandths of standard length, TLs; specimen (a) recorded first. Length to felt-for operculum 354, 300; to felt-for preoperculum 265, 225. Length to gill opening 469, 413; free length of branchial tube 35, 35; diameter, longitudinal 18, 26, transverse 27,31 . Length to fleshy eye capsule, full 93, 88, from tip of upper jaw 64,69 . Diameter of ocular capsule 73,94 , of exposed eye 40, 50. Interorbital, capsule 124, 65; eye 133, 90. Length of maxilla 208, 186; maximum width 66, 51; shortest distance from eye (capsule) 36, 25. Maximum (median) width of lower lip 27, 26. Width of mouth at angle 265,250 . Length to anterior nostril 22, 19; internarial (anterior nostrils) 62, 58. Length to first dorsal spine, 22, 19; length without lure 168, 156; length with lure 204, 179; transverse extension of 1 ure 36,50 ; basal diameter of spine $4.4,4.4$. Length to second dorsal spine 71,88 ; length of spine 132, 188; basal diameter 26,24 . Length to third dorsal spine 221 , 194; 1ength, total 168,150 , free of membrane 80,100 ; total longitudinal extent of membranous base 115,125 . Length to first dorsal ray 434,369 ; to last ray 885,794 ; base, between parallels 451,425 ; direct, ray to ray 473, 450: for lengths of dorsal rays see below. Length to first anal ray 699, 656; to last ray 916, 819; base, between paralle1s 217, 163; direct, ray to ray 226, 175: for lengths of anal rays see below. Length to vent 673,619 . Length to origin of ventral 164,106 ; length to base of first ray 190, 138; oblique length of base 97,81 ; interval between bases of first rays 106, 94, between bases of last rays 133, 125: for lengths of rays see below. Length to felt-for pectoral origin 265, 250; length of distal segment of pseudobrachium from base of gill tube to tip of longest ray 319, 263; total 1ength of pseudobrachium straightened out 425., 313: for lengths of rays see below. Depths (in parentheses widths) at front of eyes $292(204), 275(213)$, at back of eyes $354(292), 325$ (281); at operculum 451(425), 400(306); at first dorsal ray 442(407), 375(202); at vent $310(195), 275(139)$; at anal termination 168(124), 119(67); caudal peduncle, minimum dimensions $140(33), 110(24)$. In view of the flabby character of the skin, some of these measurements of depth and width are to be regarded as being best estimates.

\section{Proportions}

Some standard proportions may be noted. In standard length: head 2.8, 3.3; length to vent $1.5,1.6$; maximum depth $2.2,2.5$. In head: snout, from tip of upper jaw 6.6 , 6.0 , full 5.0, 4.7; eye, capsule $6.5,4.4$, exposed organ $11.8,8.3$; interorbital, capsule $6.5,4.4$, eyeball $8.5,8.3$; caudal peduncle, length $5.6,2.3$, depth $3.4,3.8$.

\section{Description}

(a) General form. The account in this section is based primarily on the larger individual. Stout, subequal height and width about half standard length, elevated in front, tapering tolerably evenly behind. Dorsal profile: upper lip rounded, a short subvertical segment between mouth cleft and base of illicium, thereafter slightly convex to origin of second spine, overall angle about $45^{\circ}$; between bases of second and third spines 


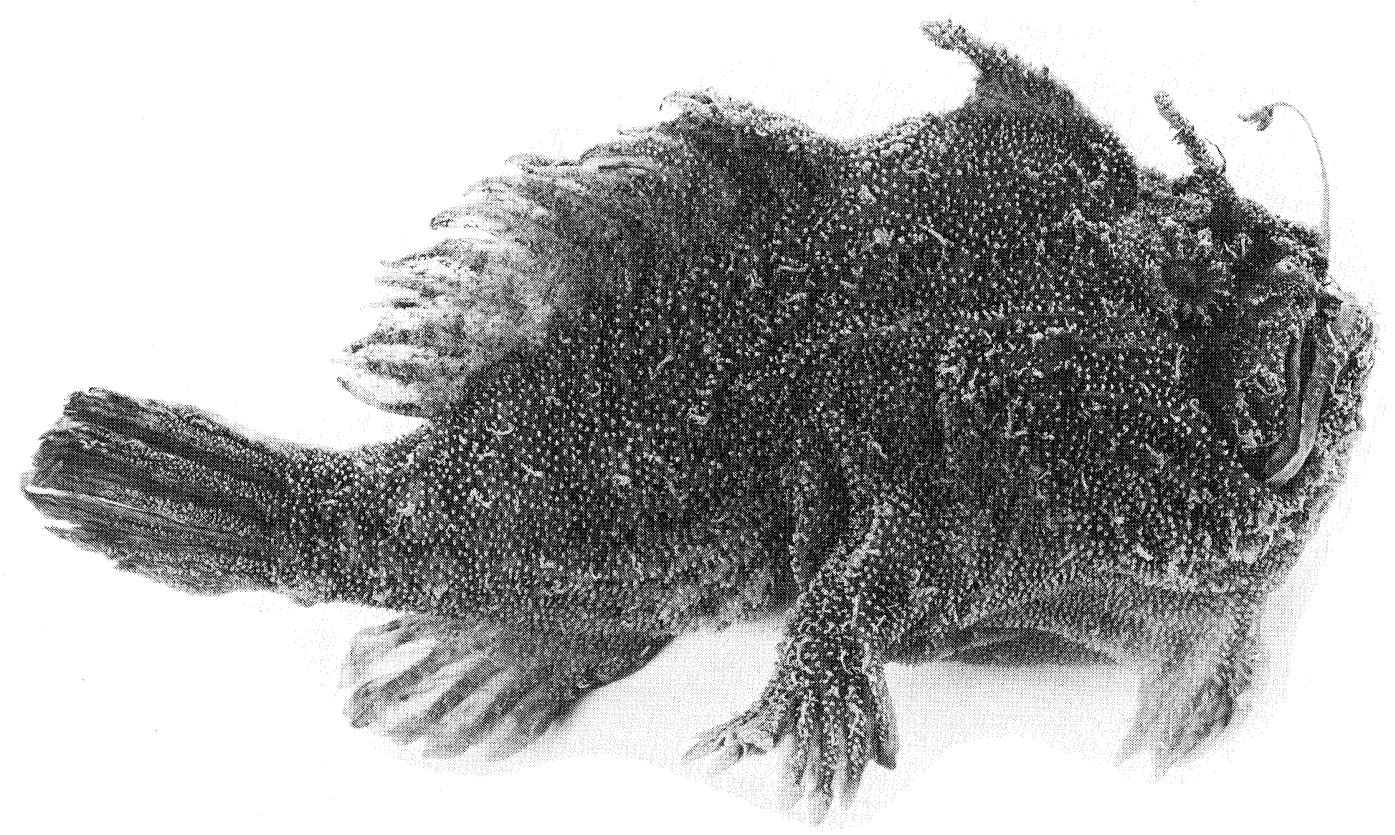

PLATE 3 - Kuiterichthys furcipilis (Cuvier, 1817). Dredged in D'Entrecasteaux Channel, southeastern Tasmania, October 1921, standard length $113 \mathrm{~mm}$; Tasmanian Museum and Art Gallery, D365, labelled Trichophryne mitchelli (Morton, 1897).

Photo: M. Bartkevicius.

virtually horizontal; third spine running obliquely backward, its anterior contour moderately convex, the somewhat recurved tip above the back by about two-fifths chord of anterior border or a little more than preorbital length, membrane of posterior border strongly backwardly concave; highest point on outline of fish near its point of attachment; between third spine and first ray virtually straight, sloping back at an angle of some $20^{\circ}-25^{\circ}$; base of soft dorsal sloping steeply down, barely convex; caudal peduncle slightly convex anteriorly, almost straight for most of its length. Ventral profile: between lower lip and insertion of ventral fin moderately round, more markedly in lower half; thereafter to vent virtually horizontal; a single convex sweep from anal origin to caudal origin, tending to straighten out on peduncle. Ventral surface between level of ventral fins and anal almost flat; some slight convexity transversely, barely recognizable longitudinally. The combination of plane under-surface and low centre of gravity makes the fish highly stable on a flat surface, considerable force being required to disturb its equilibrium. Caudal peduncle distinct, stout, its width at end of anal base subequal to its depth at caudal origin, its anterior depth about one and a third times its anterior width, which equals two-thirds anal base.

(b) Head. Large, 2.72 in Ls, subglobular, its width barely greater than its depth, the later 1.16 in its length. Operculum and preoperculum wholly enveloped in skin, the opercular region rounded and noticeably elevated, separated by a slight depression from a less prominent bulge below whole base of third dorsal spine. On right side of fish two rather obscure longitudinal ridges, somewhat upwardly and backwardly oblique, each with several papillae bearing a slender tentacle, either simple or, more commonly, branched distally. Viewed from above the region between the second and third dorsal spines, more or less horizontal in lateral aspect, bears three longitudinal ridges extending back 
from base of second spine, a medial and two lateral ones, the latter diverging backward, their distance apart behind more than one and a half times that in front, subequal to their own length or half length of second spine; this area, more or less a walled subtriangular platform, is slightly concave transversely on either side of median ridge. Eye about level with upper 1 ip and with nostril, its shortest direct distance from mouth subequal to that from base of second spine; the visible part of the ocular organ wholly surrounded by an elevated circular fleshy capsule more than half as wide again, its height subequal to eyeball diameter; top of capsule beset with upwards of a dozen short radial ridges, each bearing several, modally half a dozen, short tubercles or longer processes, at times bifid distally; at upper border of capsule two ridges markedly higher and longer than rest extend inwards from the orbit, these heavily papillate structures coming to interrupt the general flattish profile between the second and third spines, rising above the longitudinal ridges. Mouth large, almost vertical, slightly downwardly and backwardly oblique, extending to below about middle of eye; upper 1ip tumid, of approximately constant width throughout; lower lip bolster-1ike, especially laterally, widest anteriorly, there almost twice upper 1ip; both lips received laterally into a pouch with proconcave opening, its walls smooth wholly lacking the spinules abundant on adjacent integument; lower lip here and for some 1ittle distance forward overlapping the upper; on right side near its middle a row of eight minute tubercles not evident on left side. Maxilla rounded distally. Narial system consisting of two small tubes about as wide as high set on a subcircular mound flanking base of first dorsal spine at level of middle of eye, from which the posterior is distant by half diameter of eye capsule; anterior directed forward overhanging mouth, its aperture flaring, posterior directed upward, its orifice somewhat constricted. A small rounded obscurely nodulose white papilla on summit of small fleshy mound medially in upper jaw, continuous on either side with upper lip. Teeth in lower jaw of variable size, in up to three rows, closely set, interspace equal to or, more commonly, slightly less than, basal diameter, latter about onethird height; slender, conical, mostly acutely pointed, directed upward and backward. Teeth in upper jaw very irregularly arranged in $1-3$ imperfect rows, in outermost row some small, some minute; largest subequal to largest of lower jaw. Behind a gelatinous frenum an obliquely transverse group of about a dozen teeth, variable in size, on each palatine; several more, in general similar, on vomer. Tongue with scattered white papillae, simply rounded or rounded with central conical projection; no glossal teeth observed. For spinulation see next section.

(c) Borly. Together with most of the head the trunk and tail are covered with spinules, small, closely set, upwards of a hundred per square centimetre on the flank and twice as many on the belly. They exhibit both regional and individual variation. Typical examples on the flank, standing more or less erect or directed somewhat backward, are subtrapezoidal, the distal (greater) width ranging from subequal to the length to less than two-thirds of it; the free margin is crescentic, being produced laterally into short acute points (Cuvier's "villis bifurcis"). On the ventral surface in all but the most anterior part of the head, on the whole of the trunk and on the anterior one-third or so of the tail they lack the points, being reduced to subcircular flattened ossicles suggestive of paving stones. They extend on to the second and third dorsal spines and on to all rayed fins, where they are most densely set along the rays. In certain areas, notably the anterior one-fourth of the soft dorsal and a patch beneath the eye, they are interspaced with or replaced by single-pointed subconical projections; along the anterior margin of the dorsal rays these develop fine bristle-like terminal prolongations. On the odd-numbered rays of the caudal they become very closely set in the basal half or more, beyond which they tend to form two distinct linear series, this condition being found throughout the length of the even-numbered rays; this pattern is less clearly developed in the smaller individual. In the paired fins spinules are confined to a small proximal area, except upon the outer surface of the pectoral where they extend linearly along the rays. Individual variations within groups are commonly only matters of size and proportion, but here and there an ossicle with a single projection appears among others of modal bifurcate form. In the smaller individual the general situation is closely similar to that in the larger; however the concavity of the distal margin is regularly deeper and the two tips are more decisively produced. 


\section{E.0.G. Scott}

In addition to the spinules the integument bears a number of small slender fleshy projections. Of these some are quite irregularly disposed, their development being apparently adventitious: thus while the second dorsal spine of specimen (a) bears two pairs, each about one-fourth as long as the spine, the third bears three, somewhat smaller; none occurring on either spine in (b); indeed, such appendages are in general almost non-existent in (b), in which even the course of the lateral line is not evident. In (a) the lateral line, beginning below the end of the end of the membrane of the third dorsal spine, level with the upper margin of the fleshy ocular capsule runs back almost parallel with the dorsal contour, though progressively approaching it caudad, to end at base of second caudal ray. Its course is marked by a number of processes usually subcylindrical or vermiform, occasionally branched. Two series originating at the middle of the chin curve up to define the posterior margins of the preoperculum and operculum; additional scattered examples occur between these from about the level of the lower border of the orbit down to the upper insertion of the pectoral. Other tentacles, isolated or in small groups, are found on either 1ip; below the angle of the mouth (on left side largish multifid tentacle, on left several small dense tufts); tentacles and tufts above the orbit; a pair of wide flat branched tentacles on either side of base of first dorsal spine (illicium), bending inward to meet above its base; numerous elongate slender vermiform processes on lower surface of the ventral and the pectoral; a few al so on the caudal.

The vent is a small circular aperture, enclosing a small papilla; in (a) it is preceded by a proconvex arc of elevated skin. The relative positions of end of head, vent, caudal origin are adequately specified by the equation $\log \mathrm{L}=\mathrm{m} \log \mathrm{N}$, where $\mathrm{L}$ is length to feature (here TLs) and $\mathrm{N}$ is $\log \{1,2,4\}$. For (a) the value of $\mathrm{m}$ is 0.5462 , for (b) 0.6379 ; $c$ is $2.6686,2.6105$; $t 37.571^{*}, 23.338^{*}$; mean difference between predicted and observed widths $1.5 \%, 1.6 \%$.

(d) Fins. The illicium, arising from a small rounded fleshy elevation contiguous with the upper lip, barely separated on either side by a narrow tentacular tuft from a globose enlargement bearing both nostrils, is cylindrical, slender almost filamentous, narrowing somewhat distally, wholly smooth, glassy, flexible; its length in (a) a little greater than, in (b) a little less than, that of the second spine. The lure, with mass much exceeding that of the stalk, consists primarily of two apposed main lobes together forming a crescent with its free distal border briefly incised at their junction (a) or (b) there giving rise to a third process, bluntly bifid; the two lobes of the crescent in (a) very stout with width about half length, but in (b) slender tapering processes; in (a) the arms minutely tuberculate and with several insignificant secondary processes, in (b) the processes obscurely noded. Second spine stout (a), fairly stout (b), enclosed in (a) in thick, in (b) in more delicate, skin; in both specimens beset throughout with tubercles, spinules or processes, in (a) two pairs of prominent fleshy processes, in (b) processes, fine, many elongate spine-like, highly acute; tip in (a) somewhat lobate, distinctly so in (b). Third spine stouter than second, somewhat longer (a), somewhat shorter (b), than it; wholly enclosed in integument liberally beset with spinules, in (b) most, especially distally, very slender, acute; in (b) no appreciable membrane developed, but in (a) - as in figures by Cuvier and Last et al. - a distinct fold behind, here arising at basa1 one fourth of height and extending back close to halfway to base of first dorsal ray, its free border concave. Soft dorsal with 13 rays; 1 ength of its base in (a) subequal to, in (b) distinctly more than, distance of its origin from tip of snout; fairly elevated; ray tips pointed, as preserved recurved, strongly so in (b), bifurcate spinules along their length, forming a line along anterior border of free portion in (a), in (b) here usually taking the form of a series of very fine bristles; spinules on rather fleshy membrane largely restricted to basal half; in most of the fin membrane distinctly incised, barely so between last three rays in (b) last four in (a); all rays simple, except 10 th of (a), which gives rise in its distal one-fourth to a backwardly directed spur, its form and position somewhat suggestive of its being an abnormal development.

Anal subequal in height to dorsal, originating beneath its middle, terminating short$1 y$ behind it; differing noticeably in general appearance in the two specimens; rays in (a) encased in thick integument, barely extending beyond the membrane, the tips blunt, even somewhat spatulate, it not being possible to ascertain whether or no they are divided, in 
(b) first three only slightly, rest well beyond the membrane, 4 th, 5 th, 6 th terminally bifid, the tips of the rami projecting as slender points. Ventrals with five rays, inserted well forward, origin below eye; fairly close together, hind contour of bases clearly continuous in (b); separated, extend beyond outer border of ventral surface in (b), fail to do so in (a); rays wholly enveloped in integument; except for first two preaxial in (a), which are bluntly rounded distally, tips pointed, in (b) acutely, not divided; membrane incised, most markedly postaxially. Pectoral with ten undivided rays; with distal segment of pseudobrachium extended at right angles to anteroposterior axis of fish, its anterior border about level with origin of soft dorsal; rayed portion large, its area in (a) about twice in (b) about thrice area of ventral; rays very fleshy, extending well beyond membrane, particularly postaxially; tips slender tapering to acute points in (b), stouter, less sharply pointed in (a). Anal with eight rays, rounded in (a), imperfect in (b); all rays except uppermost and lowermost divided, modally for about one-fifth of length; membrane in general not, in parts slightly, incised.

The lengths of all rays other than those of caudal (fin imperfect in (b), not satisfactorily measurable in (a)) are recorded in table 5. They present a common pattern, increasing to before or beyond the middle one, then decreasing regularly. In a loglog plot the lengths of the ascending set are a linear function of the serial numbers of the rays counting caudad, those of the descending set a linear function of serial numbers counted cephalad, i.e. $L=b N^{k}$, where $L$ is length, $N$ a natural number indicative of serial position, the exponential formulation on rectification yielding a linear graph. Table 5 sets out the parameters of the rectified equations and predicted and measured lengths, accompanied by an indication of statistical significance. The patterns in the two specimens are the same with one exception, the maximum height of the anal occurring at the 6th ray in (a) at the 5 th in (b).

\section{Coloration}

The ground color, noted by Last et al., presumably with reference to fresh material, as whitish or pinkish, is in (a) dark brownish in the anterior two-thirds, lighter behind, in (b) more or less uniform faintly purplish dark grey. Ventral surface pale yellowish (a), whitish (b). "Margin of soft dorsal fin blackish or purplish" (Last et al.): (a) without ornamentation; (b) with conspicuous blackish tips to 1 ast seven rays, the marking progressively becoming more extensive caudad, finally involving one-third length of fin. Spot on base of dorsal reported as usually present occurs in (b), quite conspicuous near end of anterior one-third of base, rounded, blackish, extending briefly on to dorsum, absent in (a). Specimen (b) without noticeable body markings, but (a) with numerous small rounded dark brown or rufous spots, most evident in hinder half, where they contrast more strongly with the somewhat lighter ground color, a few small obscure blotches. Illicum orange in (a) off-white in (b), in both some evenly spaced purplish spots. Lure in (a) pale orange, a few minute specks of purple around point of attachment; in (b) whitish, several purple spots proximally and distally, three purple spots or imperfect annuli on each main process. Second and third spines in (a) medium brown; in (b) second whitish, third grey, faintly purplish. Soft dorsal in (a) medium brown in anterior one-third, becoming light brown behind; in (b) greyish with whitish bar below black-tipped rays. In (a) anal, pectoral, ventral mostly dark flesh-colour, in (b) mostly whitish or pale grey, with in each case some extension of dark body color on to upper surface of pectoral; in (a) caudal medium brown with a tinge of purple; in (b) greyish, some blackish spots on bases of upper five rays, most developed on uppermost, here involving more than half ray, two small black spots on lowermost ray.

\section{Metrical patterns}

(a) Outline in plan. The outline of the ventral surface is elegantly petaliform. subparabolic in front, reaching its maximum width shortly before the middle of the length, thereafter curving in to a continually narrowing caudal segment. Ten measurements of width have been made at equal intervals between snout tip and level of vent. These are fitted with a high degree of accuracy $(R$ 0.998) by the following third degree polynomial, in which $N$ is serial number of measurement, proceeding caudad:

$$
W=166.8+127.79 N-18.826 N^{2}+0.6616 N^{3}
$$

predicted (measured) widths, TLS, 276(274), 354(354), 400(407), 419(416), 418(407), $398(398), 366(372), 323(327), 274(274), 224(221)$. 
Kuiterichthys furcipilis (Cuvier, 1817)

Parameters of rectified equations of logarithmic length of ray on logarithm of serial number of ray (anterior rays counted caudad, posterior cephalad), together with predicted and measured lengths. Two Tasmanian specimens, standard Parted (a) 113 post (b) 80 cephalad), together with predicted and

\begin{tabular}{|c|c|c|c|c|c|c|}
\hline \multirow{2}{*}{ Fin } & \multirow{2}{*}{ Specimen } & \multirow{2}{*}{$\begin{array}{l}\text { Ray or } \\
\text { spine } \\
\text { set }\end{array}$} & \multicolumn{2}{|c|}{ Parameters } & \multirow{2}{*}{ Predicted (measured) lengths, TLs } & \multirow{2}{*}{$t$} \\
\hline & & & Gradient & Intercept & & \\
\hline \multirow[t]{2}{*}{ Dorsal } & (a) & $\{1-8\}$ & 0.1522 & 2.0909 & $\begin{array}{l}123(125), 137(138), 146(146), 152(149), 158(153), \\
162(158), 166(165), 169(179)\end{array}$ & $9.663 * * *$ \\
\hline & & $\{13-8\}$ & 0.2448 & 2.0702 & $\begin{array}{l}118(118), 139(138), 154(156), 165(168), 174(175), \\
182(179)\end{array}$ & $12.515 * * *$ \\
\hline \multirow[t]{2}{*}{ Pectoral } & (a) & $\begin{array}{l}\{1-4\} \\
\{10-5\}\end{array}$ & $\begin{array}{l}0.2813 \\
0.2094\end{array}$ & $\begin{array}{l}2.1036 \\
2.0352\end{array}$ & $\begin{array}{l}129(125), 154(158), 173(175), 188(183) \\
108(108), 125(125), 136(138), 145(146), 152(150), \\
158(158)\end{array}$ & $\begin{array}{l}10.492 * \\
46.285 * *\end{array}$ \\
\hline & (b) & $\begin{array}{l}\{1-4\} \\
\{10-5\}\end{array}$ & $\begin{array}{l}0.1887 \\
0.2348\end{array}$ & $\begin{array}{l}2.1649 \\
2.0992\end{array}$ & $\begin{array}{l}146(145), 167(169), 180(181), 190(188) \\
125(126), 148(149), 163(163), 174(175), 183(185), \\
191(189)\end{array}$ & $\begin{array}{l}13.117^{*} \\
36.313^{* * *}\end{array}$ \\
\hline Ventral & (a) & $\begin{array}{l}\{1-3\} \\
\{5-3\} \\
\{1-3\} \\
\{5-3\}\end{array}$ & $\begin{array}{l}0.2620 \\
0.3129 \\
0.3440 \\
0.4073\end{array}$ & $\begin{array}{l}2.0512 \\
2.0257 \\
1.9610 \\
1.9189\end{array}$ & $\begin{array}{l}113(113), 135(135), 150(150) \\
106(106), 132(131), 150(150) \\
91(91), 116(117), 133(133) \\
84(84), 112(106), 132(133)\end{array}$ & $\begin{array}{l}314.662^{*} \\
48.647^{*} \\
27.975^{*} \\
7.262\end{array}$ \\
\hline \multirow[t]{4}{*}{ Anal } & (a) & $\{1-6\}$ & 0.3049 & 2.0486 & $\begin{array}{l}112(114), 139(134), 156(157), 171(168), 183(186), \\
193(195)\end{array}$ & $19.463^{*}$ \\
\hline & & $\{8-6\}$ & 0.6260 & 1.9850 & $197(197), 149(146), 190(195)$ & $19.125 *$ \\
\hline & (b) & $\{1-5\}$ & 0.4049 & 1.9444 & $89(88), 116(114), 137(145), 154(156), 169(163)$ & $10.016 * *$ \\
\hline & & $\{8-5\}$ & 0.2245 & 2.0744 & $162(163), 152(151), 139(139), 119(119)$ & $90.255 * * *$ \\
\hline
\end{tabular}


(b) Anal rays. These comprise two sets in respect of length, the anterior, $A\{1-6\}$ and the posterior, $P=\{8-6\}$, the sequence of the members of the set being that of increasing magnitude, in $A$ caudad, in $P$ cephalad; $A \cap P ; x=6$. In each set the logarithmic lengths of the rays are a linear function of the logarithms of their numbers. With counting caudad $(N)$ in $A$, cephalad $\left(N^{\prime}\right)$ in $P$ the slope is in each case positive.

A. $\log L=0.3007 \log N+1.1362 ; t 58.091 * * *$ ( 20.9994$) ;$ predicted (measured) lengths, TLs, $114(114), 140(140), 159(158), 173(175), 185(183), 195(196)$.

B. $\log L=0.6887 \log N^{\prime}+1.9607 ; t 45.892 *(r 0.9998) ; 91(92), 147(146), 195(196)$.

Similar linear loglog patterns of fin-ray length, with caudad and cephalad increase have been noted in these contributions as characterizing a number of diverse species.

(c) Pectoral rays. The pattern of $10 \mathrm{~g}$ ray-length a linear function of $10 \mathrm{~g}$ serial number of ray found in anal rays obtains also in pectoral rays, with $A=\{1-4\}, P=\{10-5\}$; however, here the elements of $A$ are more numerous than those of $P$, and $A \cup P$. Left fin measured. The ray counted as the first is the uppermost, preaxial (Scott 1974).

A. $\log L=0.2813 \log N+2.1036 ; t 10.492 * *(r 0.991)$; predicted (measured) 1 engths, TLs, $129(125), 154(158), 173(175), 188(183)$.

P. $\log L=0.2094 \log N^{\prime}+2.2035 ; \quad t 37.792 * * *(r 0.9986) ; 108(108), 125(125), 136$ $(138), 145(146), 152(150), 158(158)$.

Loglog patterns for the pectoral involving two or more sets have been reported for various other species.

(d) Dorsal rays. The profile of the soft dorsal is in large part not far from rectilinear, with some visually insignificant decrease in altitude at either end. The pattern comprises an anterior ascending set, $A=\{1-8\}$ and a posterior descending set, $P=\{8-13\} ; A \cap P ; x=8$. In a loglog formulation the equations for the best straight lines are as below; $N, N^{\prime}$ as before:

A. $\log L=0.1522 \log N+2.0909 ; t 9.663 * * *(r 0.9969) ;$ predicted (measured) 1 engths, TLs, 123(125), 137(139), 146(146), 152(149), 158(158), 162(158), 166(165), 169(179).

$P$. $\log L=0.2448 \log N^{\prime}+2.0702 ; t 12.513 * * *(r 0.997) ; 182(179), 174(175), 168$ $(165), 154(156), 139(138), 118(118)$

(e) Ventral rays. In ventral fins with the most common formula, I, 5, the usual arrangement is that the fin elements increase in length from the first - by definition (Scott 1974) that furthest from the spine, or nearest midventral line of fish, postaxial - to the fourth, decreasing through the fifth to the spine; a loglog length-number relation has been found to be widespread. This pattern obtains here as far as relevant, rays increasing up to fourth. The logarithmic length-number formulation yields a straight line. Left fin measured.

$\log L=0.1945 \log N+1.9976 ; t 29.608 * *(r 0.998) ;$ predicted (measured) lengths, TLs, 99(100), $114(113), 128(125), 130(131)$.

(f) Caudal rays. The contour of the posterior border of the caudal, patently asymmetric, is found to be resolvable into three arcs, each a first degree function of log length and log serial number of ray. The graphed line is continuous, $A\{9-7\} \cap B=\{7-4\} \cap$ $C=\{4-1\}$; $A$ and $B$ with positive slope, $A$ the steeper, $C$ with negative slope. With conventional treatment of uppermost ray as first (Scott 1974), the initial (left hand) point on the graph is that for the ninth (shortest) ray. Though the hind profile is asymmetric, the area, when formulated as above, presents a noteworthy aspect of symmetry, the area under the graph for $A, 1.144$, being significantly equal to the sum for $B(0.729)$ and $C$ (0.412); units common logarithms and thousandths of standard length. It is possibly adventitious that these three values are significantly linear ( $t$ 13.683*) on the logarithms of the first three integers.

A. $\log L=0.3871 \log N^{\prime}+2.2239 ; t 19.239 *(r 0.9987)$; predicted (measured) lengths, TLs, $167(167), 219(222), 262(254)$.

B. $\log L=0.1138 \log N^{\prime}+2.3489 ; t 11.119 * *(r 0.984) ; 253(254), 261(259), 268(269)$, $274(274)$. 
C. $\log L=-1.1624 \log N^{\prime}+3.3610 ; t 7.956 *(r-0.9698) ; 286(274), 239(258), 205$ (203), 179(175).

(g) Dorsal fin origins. When the logarithmic lengths to the three separate elements of the dorsal are graphed against the logarithms of the first three natural numbers, they give a statistically straight line $\left(r 0.991, t 23.055^{*}\right)$. When the line is produced and the logarithm of the length to the first ray of the main dorsal is considered in relation to this extension, it is apparent it is appropriately sited on $\log 5$ ( $r 0.9994$, $t$ $79.956 * * *)$. The slope of the relevant equation for the four dorsal fin rays is $10 \mathrm{~g} 1.7423$, the intercept 1.4127; predicted (measured) values, TLs, 26(25), 87(92), 174(175), 427(411).

(h) Head length, length to vent, standard length. In a wide range of species it has been found the logarithms of these primary dimensions are collinear on the logarithms of three early natural numbers, the most commonly encountered sets being $\{1,2,3\}$ and $\{1,2,4\}$. The present data are adequately specified by the latter set; length of head being treated as length to opercular margin.

$\log L=0.7231 \log N+2.5613 ; t 37.630 *$ (r 0.9996); predicted (measured) lengths, TLs, $364(367), 601(592), 992(1000)$.

\section{ACKNOWLEDGEMENTS}

Material has been made available through the courtesy of $\mathrm{Mr}$ C.B. Tassel1, Director, Queen Victoria Museum and Art Gallery, and the Museum's Zoologist, Mr R.H. Green; Mr D.R. Gregg, Director, Tasmanian Museum and Art Gallery, Hobart, and the Museum's Zoologist, Mr A.P. Andrews; Fisheries Development Authority, Hobart, through Dr P.R. Last; Mr Mark Purton. I am indebted to Dr J.R. Paxton for a copy of Cuvier's paper on Antennariidae, and to Mr Rudie Kuiter for information on Kuiterichthys furcipizis (Cuvier, 1817). The photographs have been taken by Mr R.H. Green, and Mr M.A. Bartkevicius, the graphs prepared by Mrs Rhonda Hamilton and Miss Anne Hastings, and the manuscript typed by Miss Joanne Damon - to each my lively thanks.

\section{REFERENCES}

Agassiz, L.J.B., 1845: NOMENCLATOR ZOOLOGICA: PISCES. Soloduri.

Anon., 1956: (Yellow eel, Victoria.) Anglers' Digest and Shooters' Monthly, Oct.: 121. Bachus, R.H., Craddock, J.P., Haedrich, R.L. \& Shores, F.L., 1969: Mesopelagic fishes and thermal fronts in the western Sargasso Sea. Mar. Biol., 3: 87-108.

Beaufort, L.F. de \& Briggs, J.C., 1962: FISHES OF THE INDO-AUSTRALIAN ARCHIPELAGO, vol.II. E.J. Brill, Leiden.

Bertanlanffy, L. von, 1938: A quantitative theory of organic growth. Hum. Biol., 10: $181-243$ [n.s.].

Bleeker, P., 1868: Description et figure d'une nouvelle espèce de Trachypterus de l'Ile d'Amboine. Arch. Neerl. Sci. Nat., 3: 279-280, fig.

Bonelli, F.A., 1820: Description d'une espèce de poisson de la Mèditerranée appartenant au genre Trachyptère avec des observations sur les caractères de ce même genre. R. Accad. Sci. Tomino, Mem., 24: 285-294, fig.

Clarke, F.E., 1881: Description of a new species of Trachypterus. Trans. N.Z. Inst., 13: 195-199, unnumbered fig.

Cuvier, G.C.L.D., 1817: Sur le genre Chironectes Cuv. (Antennarius Commers.) Mém. Mus. Hist. Nat., 3.

Ehrenbaum, E., 1905: Nordisches Plankton. Eier und Larven von Fischen, 4: 125-128, 3 figs.

Emery, C., 1879a: Le metamorfosi del Trachypterus taenia. R. Accad. Lincei, Atti, ann., 276, ser.3. Mem. Cl. Fis. Mat. Nat., 3: 390-397.

1879b: Contribuzioni all'Ittiologia. 1.Le metamorphosi del Trachypterus taenia. Zool. Stat. Neapel, Mittheil, I(4): 581-592.

Endean, R., 1957: The biogeography of queensland's shallow-water echinoderm fauna (excluding Crinoidea) with a rearrangement of the faunistic provinces of tropical Australia. Aust. J. Mar. Freshw. res., 8: 233-273, figs 1-5. 
Fitch, J.E., 1964: The ribbon fishes (family Trachipteridae) of the Eastern Pacific Ocean, with a description of a new species. Calif. Fish Game, $50(4): 228-240$, figs $1-5$.

Gist1, 1848: NATURGESCHICHTE DES THIERREICHS, 8. Stuttgart.

Gmelin, J.F., 1788: CAROLI A LINNE ... SYSTEMA NATURA, 1(3). Delamolliere, Leiden. Goldfuss, G.A., 1820: HANDBOCH DER ZOOLOGIE, 2(3). Nuremburg.

Grant, E.M., 1978: GUIDE TO FISHES. Dept Harbours and Marine, Brisbane.

Greenwood, P.H., Rosen, D.L., Weitzman, S.H. \& Meyers, G.S., 1966: Phyletic studies of teleostean fishes with a provisional classification of living forms. BuZZ. U.S. Mus. Nat. Hist., $131(4)$

Haedrich, R.L., 1967: The stromateoid fishes: systematics and classification. BulZ. Mus. Comp. Zool. Harvard, 115(2): 31-39, 56 figs.

Hamilton, H., 1916: Notes on the occurrence of the genus Trachipterus in New Zealand. Trans. N.Z. Inst., 43: 370-382, figs 1-6.

Haukioja, E. \& Hakala, T., 1979: Asymptotic equations in growth studies - an analysis based on Anodonta piscinala (Mollusca, Unionidae). Ann. Zool. Fennici, 16(2): 115122 , figs $1-3$.

Haysom, 1960: (Xanthism in fish.) QZd Inform. BulZ., 17(2).

Hedley, C., 1904: The effect of the Bassian isthmus upon the existing fauna, a study in ancient geography. Proc. Linn. Soc. N.S.W., 28: 876-883.

Hubbs, C.L., 1926: The metamorphosis of the Californian ribbon fish, Trachypterus rexsalmonorum Mich. Acad. Sci., Arts, Lett., Pap. 5: 469-476.

Hutton, F.W., 1873: Contribution to New Zealand ichthyology. Trans. N.Z. Inst., 5: 259-272, pls 7-11. $209-218$.

$$
\text { , 1876: Contribution to New Zealand ichthyology. Trans. N.Z. Inst., 8: }
$$

, 1904: Description of a new fish. Trans. N.Z. Inst., 36: 148-149.

Iredale, T., 1937: A basic list of the land molluscs of Australia. Aust. Zoo ., 8(4). 199-273, pls 13-17, map.

Jacino, A., 1909: Uova e larve di Trachypterus sp. Arch. Zool. Napoli, 3(4): 479-484. Johnston, R.M., 1883a: General and critical observations on the fishes of Tasmania; with a classified catalogue of all known species. Pap. Proc. R. Soc. Tasm. (1882): 53144 .

, 1883b: Note on Clinus despicizlatus Richardson and Bovichthys variegatus ibid. Pap. Proc. R. Soc. Tasm. (1882): 170.

, 1891: Further observations upon the fishes and fishing industries of Tasmania, together with a revised list of indigenous species. Pap. Proc. R. Soc. Tasm. (1890): 22-46.

Jordan, D.S. \& Snyder, J.O., 1901: Description of nine new species of fishes contained in museums of Japan. J. Coll. Sci. Imp. Univ. Tokyo, 15(2): 311, figs 9,10.

Kershaw, J., 1904: (Xanthic eel). Vict. Nat., 20: 140.

Kott, O., 1952: The Ascidians of Australia. Stolidobrachiata Labill. and Phlebobranchiata Labill. Aust. J. Mar. Freshw. Res., 3: 207-333, figs 1-183.

Kruger, F., 1962: Uber die mathematische Darstellung der tierischen Wachstums. Naturwissenschafter, 49: 454

Last, P.R., Scott, E.O.G. \& Talbot, F.H., 1983: FISHES OF TASMANIA. Tasm. Fish. Devel. Auth., Hobart.

Linné, C. von, 1758: SYSTEMA NATURAE, ed.10. Holmiae, Paris.

Lo Bianco, S., 1908: Uova e larve di Trachypterus taenia Bl. Zool. Stat. Neapel. Mittheil., 19(1): 1-17.

Lord, C.E., 1923: A list of the fishes of Tasmania. Pap. Proc. R. Soc. Tasm. (1922): $60-73$.

, 1927: A list of fishes of Tasmania. J. Pan-Pac. res. Inst., 2(4): 11-16. \& Scott, H.H., 1924: A SYNOPSIS OF THE VERTEBRATE ANIMALS OF TASMANIA. Oldham, Beddome \& Meredith, Hobart.

Marshall, T.C., 1926: New fish records for Queensland. Mem. QZd Mus., 8(2): 123-124. McCann, C., 1953: Ichthyological notes, with special reference to sexual dimorphism in some New Zealand fishes. Rec. Domin. Mus., 2(1): 1-17, figs 1-17.

M'COY, F., 1878: PRODROMUS OF THE ZOOLOGY OF VICTORIA, 2. Government Printer, Melbourne. , 1886: PRODROMUS OF THE COOLOGY OF VICTORIA, 13. Government Printer, Melbourne. 
McCulloch, A.R., 1921: Check-list of the fish and fish-like animals of New South Wales. Part 2. Aust. Zool., 2(2): 14-56, pls 4-24. , 1922: Check-list of the fishes and fish-like animals of New South Wales. Part 3. Aust. Zool., 2(3): 86-130, pls 25-43.

, 1929: A Check-list of the fishes recorded from Australia. Aust. Mus. Mem., 5(1-4; part 4, index, 1930).

\& Waite, E.R., 1918: Some new and little-known fishes from South

Australia. Rec. S. Aust. Mus., $1(1): 39-78$, pls 2-7, text figs 26-31.

\& Whitley, G.P., 1925: A list of the fishes recorded from Queensland waters. Mem. QZd Mus., 8(2): 125-182. Angus \& Robertson, Sydney.

$$
\text { , 1958: Fishes. In: AUSTRALIAN ENCYCLOPEDIA. } 4 .
$$

Macleay, W., 1881: Descriptive catalogue of the fishes of Australia. Part 2. Proc. Linn. Soc. N.S.W., 5(4): 510-629.

, 1881-1884: Descriptive catalogue of the fishes of Australia. Proc. Linn. Soc. N.S.W. 1881, 5(3): 302-444 and 5(4): 510-629, pls 13,14. 1882, 6(1): 1-138, pls 1,2 and $6(4): 202-387$. $1884,9(1): 2-64$.

Morton, A., 1897: Antennarius mitchellii, sp. nov. Pap. Proc. R. Soc. Tasm. (1896): XIV and 98 .

Munro, I.S.R., 1956-1961: Handbook of Australian Fishes. In: Fisher. Newst. (now Aust. Fisher.), $15(7)-20(12)$.

, 1957: Handbook of Australian fishes, 15: 61-64, figs 431-453. In: Fisher. Newst. (now Aust. Fisher.), $16(9)$.

Ogilby, J.D., 1886: Catalogue of the fishes of New South Wales with their principal synonyms. Rept Commis. Fisher. N.S.W. appendix A: 1-67.

, 1898: On a Trachypterus from New South Wales. Proc. Linn. Soc. N.S.W., $22(3): 646-659$.

Palmer, G., 1961: The dealfishes (Trachipteridae) of the Mediterranean and north-east Atlantic. Bull. Brit. Mus. (Nat. Hist.), 7(7): 337-351, p1.62.

Parrott, A.W., 1949: Studies in N.Z. fishes. Rec. Canterb. Mus., 5(3): 137-160, pls 3031 .

Pietsch, T.W., 1984: The genera of frog fishes (family Antennariidae). Copeia, 1: 27, 44.

Phillipps, W.J., 1927: Bibliography of New Zealand fishes. N.Z. Mar. Dept Fisher. BuZ2., 1: 6-68.

, 1944: An immature Trachipterus from French Pass. Rec. Domin. Mus., 1(2): 120-122, pl.52 (color)

Ramsay, E.P., 1881: On a new species of Regalaecus from Port Jackson. Proc. Linn. Soc. N.S.W., 5: 631-633, pl.20.

Regan, T.C., 1913: Antarctic fishes of the Scottish national antarctic expedition. Trans. R. Soc. Edinb., 49(2): 229-291, pls 1-9.

Richardson, J., 1841: On some new or little known fishes from the Australian Seas. Proc. Zool. Soc. (Lond.), 9: 21-22.

London. , 1846: ZOOL. VOY. EREBUS AND TERROR (1844-48). Fish. E.W. Janson,

Ricker, W.E., 1958: Handbook of computations for biological statistics of fish populations. Bull. Fish. Res. Bd Can., 119: $300 \mathrm{pp}$.

Sanzo, L., 1918: Uova e larve di Trachypterus cristatus. Bp. R. Com. Talass. Ital., Mem. 64 .

Schmidt, E.J., 1928a: The fresh-water eels of New Zealand. Trans. N.Z. Inst., 58: 379-388, figs $1-8$.

, 1928b: The fresh-water eels of Australia. With some remarks on the short-finned species of Anguizza. Rec. Aust. Mus., 16(4): 179-210, figs 1-14.

Schultz, L.P., 1957: The frogfishes of the family Antennariidae. Proc. U.S. Nat. Mus., $107,3383: 47-104$, pls 1-14.

, 1966: Family Antennariidae: anglers; frogfishes. In: Fishes of the Marshall and Mariana Islands, 3. L.P. Schultz \& collaborators, L.P. Wood \& E.A. Lachner. U.S. Nat. Mus. BulZ., 202, 3: 138-146, p1.146. 
Scott, E.O.G., 1934-1983: Observations on some Tasmanian fishes. Pap. Proc. R. Soc. Tasm.; 1935, II: 62-73, pl.5. 1942, V: 45-54, pl.7. 1953, VI: 141-166, figs 1-4. 1957, VIII: 145-146. 1960, IX: 87-102, fig.1. 1974, XIX: 87-102, fig.1. 1978, XXIV: 289-356, figs 1-3. 1979, XXV: 99-148. 1980, XXVI: 85-144, pls 1,2, figs 1,2. 1982, XXVII: 181-217, pls 1-4, figs 1-9. 1983, XXIX: 167-202, figs 1-6, pls 1-3.

Scott, T.D., 1962: THE MARINE AND FRESH WATER FISHES OF SOUTH AUSTRALIA. Government Printer, Adelaide. , Glover, C.J.M. \& Southcott, R.V., 1974: THE MARINE AND FRESHWATER FISHES OF SOUTH AUSTRALIA. Government Printer, Adelaide.

Smith, H.M., 1912: In: Smith, H.M. \& Radcliffe, L., New pediculate fishes from the Philippine Islands and contiguous waters. Proc. U.S. Nat. Mus., 42: 199-214, pls 1-12, figs 1-3.

Smitt, F.A., 1893: A HISTORY OF SCANDINAVIAN FISHES (Ed.2). Stockholm and London. Spartà, A., 1932: Trachypteridae e Regalecidae. In: Faune e flora del Golfo di Napoli Uova, larve e stadi giovanili del Teleostei. Staz. Zool. Napoli, monogr. 38: 269279 .

Springer, V.G. \& Fraser, T.H., 1976: Synonymy of the fish families Cheilobranchidae (= Alabetidae) and Gobiesocidae, with descriptions of two new species of Alabes. Smithsonian Contrib. Zool., 234.

Stead, D.G., 1906: FISHES OF AUSTRALIA. William Brooks, Sydney.

1913: Exhibition of photographs of a specimen of Trachypterus jacksonensis. Proc. Linn. Soc. N.S.W., $37(3): 492$.

Valenciennes, A., 1831: In: Cuvier, G. \& Valenciennes, A., HISTOIRE NATURELIE DES POISSONS, 10. Levrault, Paris.

Verhulst, P.F., 1838: Notice sur la loi que la polulation suit dan som accroissement. Corresp. Math., 10: 113-131.

Waite, E.R., 1909: THE SUBANTARCTIC ISLANDS OF NEW ZEALAND (Vertebrata in vol.2). Government Printer, Wellington.

Walters, V. \& Fitch, J.E., 1960: The families and genera of the lampridiform (Allotrignath) suborder Trachipteroidei. Calif. Fish Game, 46(4): 441-451.

Whitley, G.P., 1927: Studies in Ichthyology. No.1. Rec. Aust. Mus., 15 (5): 289-304, pls 34,35 , and fig.

, 1932: Marine zoogeographical regions of Australia. Aust. Nat., 8: 166. , 1937: The Middleton and Elizabeth Reefs, South Pacific Ocean. Aust. Zool., 8(4): 199-273, pls 13-17, map.

, 1940: THE FISHES OF AUSTRALIA. Part 1. THE SHARKS, RAYS, DEVIL-FISH AND OTHER PRIMITIVE FISHES OF AUSTRALIA AND NEW ZEALAND. Royal Zoological Society, Sydney.

'1952: Some noteworthy fishes from eastern Australia. Proc. R. Zool.
Soc. N.S.W., 1950/51: 27-32, figs 1-5.

, 1958: Fishes. AUSTRALIAN ENCYCLOPEDIA. Angus \& Robertson, Sydney.

, 1964: Presidential Address: A survey of Australian Ichthyology.

Proc. Linn. Soc. N.S.W., 89: 11-127.

, 1968: A check-list of the fishes recorded from the New Zealand region. Aust. Zool., 15(1): 1-102, figs 1,2.

Winsor, C.P., 1932: The Gompertz curve as a growth curve. Proc. Nat. Acad. Sci., U.S.A., 18: $1-18$. 